Chiara Ardito*

\title{
The unequal impact of raising the retirement age: Employment response and program substitution
}

\begin{abstract}
Using high-frequency Italian administrative data, the author studies the heterogeneous effects of a reform raising the normal retirement age (NRA) from 60 years to 65 years for privatesector male employees. The analysis, based on a difference-in-differences (DD) method, shows that the NRA raise reduces pension benefit claims but does not lead to a one-to-one increase in the employment rate since workers also apply for more disability and unemployment benefits. Moreover, most of them simply retire without any benefit. The extent of the effects varies substantially across socio-economic groups, as individuals with poorer health, with lower occupational grades and lower pay levels are the most constrained by the reform, experiencing the highest delay in pension claims, increase in employment, and inactivity. All in all, this paper shows that raising the NRA could have unintended effects as it affects more negatively the most vulnerable in the labor market.
\end{abstract}

$\begin{array}{ll}\text { Current version: } & \begin{array}{l}\text { August 09, } 2021 \\ \text { Keywords: }\end{array} \\ & \text { Retirement age, Labor supply, Disability benefit, Pension reform, } \\ & \text { Unemployment, Older workers, Socio-economic inequalities } \\ \text { JEL-codes: } & \mathrm{J} 14, \mathrm{~J} 26,138, \mathrm{~J} 18, \mathrm{~J} 22 \\ \text { Corresponding author: } & \begin{array}{l}\text { Ardito Chiara } \\ \text { chiara.ardito@unito.it }\end{array}\end{array}$

Department of Economics and Statistics “Cognetti de Martiis”, University of Torino \& LABORatorio R. Revelli, Lungo Dora Siena 100 A, 10153 Torino, Italy.

(c) The Author(s). 2021 Open Access This article is distributed under the terms of the Creative Commons Attribution 4.0 International License (http://creativecommons.org/licenses/by/4.0/), which permits unrestricted use, distribution, and reproduction in any medium, provided you give appropriate credit to the original author(s) and the source, provide a link to the Creative Commons license, and indicate if changes were made. (-) - Cite as: Ardito. IZA Journal of Labor Economics (2021) 10:03. 


\section{Introduction}

In the past decades, most countries around the world have seen a substantial increase in average life expectancy and a tendency toward early retirement, with negative effects on tax revenues and the capacity of governments to fund social welfare systems (Gruber and Wise, 1999). The need to ensure the long-run financial sustainability of pension systems has prompted keen debate and generated the political capital to reform social security systems in almost all countries in the western world (Börsch-Supan, 2015).

In many countries, pension rules feature two statutory retirement ages: an early retirement age (ERA) and a normal retirement age (NRA). Whereas the former is the age at which pension can be claimed at a reduced rate or eligibility conditions, the latter is the age at which individuals qualify for a full pension benefit. In this paper, I have examined the labor market effects of one of the earliest European national structural pension reforms of the NRA. In 1992, Italy has to some extent pioneered the European season of pension reforms, by lifting the NRA by 5 years for both men and women. Thus, Italy's experience can be useful to understand and anticipate the consequences of raising the NRA also for other countries. The reform was implemented gradually, and it affected workers differently depending on the year of birth. This exogenous variation in statutory pension age between birth cohorts allows me to identify the causal effect of the reform using a difference-in-differences (DD) estimation strategy. Through this approach, cohort and age are used as group and time variables respectively, following a relatively standard practice in the pension age reforms literature (Staubli and Zweimuller, 2013; Cribb et al., 2016; Hanel and Riphahn, 2012; Soosaar et al., 2021).

The empirical investigation is based on micro-level data from Italian social security registers covering a random sample of the entire population of male private-sector workers. The first objective of this work is to assess whether and to what extent the NRA raise was able to delay pension claims and extend working life. Second, I investigate whether this tightening also generated "unintended" effects, by eliciting an increase in the demand for other social security benefits, e.g., disability pensions and unemployment subsidies, or by increasing the proportion of inactive individuals, e.g., retiring without benefits. In fact, there is the possibility that a measure that restricts access to retirement might drive persons unable to extend their working lives (because of health, low-quality jobs, or limited employment opportunities) out of the labor market. Finally, as standard life cycle theories of individual behavior suggest, an increase in the pensionable age is likely to affect workers facing unfavorable labor market, financial, or health conditions in different ways, due to higher liquidity constraints. Therefore, I extend over a wide spectrum investigation into the presence of socio-economic gradients in the responses to this reform. This is a distinctive feature of the paper, as most of the previous studies disregarded socio-economic inequalities as a possible mechanism mediating the effect of pension reforms on labor market outcomes.

This paper adds to the current literature by studying a large and relatively rapid rise applied to the NRA on previously unexplored outcomes. In fact, existing evaluations of reforms of the NRA limited their attention mostly to retirement behaviors (Mastrobuoni, 2009; Hanel and Ripham, 2012; Soosaar et al., 2021) or on the need to take up alternative social security programs (Duggan et al., 2007; Oguzoglu et al., 2020), while I have the possibility of looking at both labor supply and benefits that accrue focusing also on the inflow into inactivity, which is 
novel in the literature. Studying an NRA reform is particularly relevant, since raising the NRA (rather than ERA) implies a target composed of older individuals, with a lower time to adjust their behavior to the new incentives, and generally with lower labor market attachment and employability in case of job loss. Consequently, affected individuals may experience disproportionate difficulty in adapting to the challenges posed by the pension reform.

This work also provides important methodological improvements with respect to earlier studies on pension age reforms. Despite that most of existing pension age reforms share a staggered implementation design, to the best of my knowledge this is the first study to employ a DD estimator specifically designed for studying staggered interventions, which is unbiased even in the presence of a treatment effect that is heterogeneous across groups or time (de Chaisemartin and D'Haultfoeuille, 2020a, b). Moreover, this study reports wild bootstrapped standard errors, as recommended by Bertrand et al. (2004) and Cameron et al. (2008), who showed that conventional DD clustered standard errors at cohort or period level may severely understate the true standard deviation. Finally, this study explicitly considers that when analyzing multiple outcomes, the probability of rejecting the null when it is true increases with the number of tests (Abdi, 2007). Accordingly, the Šidàk correction of $p$-values for multiple hypothesis testing is adopted to account for this multiple testing problem.

The results suggest that raising the NRA induced significant responses. The probability of pension claims reduced by 44 percentage points while employment rates increased by about 9 percentage points. Furthermore, I find that the reform caused substantial program substitution. The raise in NRA led to an increase in disability benefit take-up by 4 percentage points, corresponding to $>100 \%$ increase with respect to pre-reform levels. The inflow into inactivity experienced the largest growth, which exceeded the direct impact on labor force participation. The impact of raising the NRA however varies substantially across workers, with individuals from lower socio-economic backgrounds showing the largest reaction to the reform, while highly skilled and highly paid workers exhibit very limited or null responses.

The paper proceeds as follows. The next section discusses the literature and highlights the contribution of this paper. Section 3 details the institutional background and the features of the above-mentioned reform. In Section 4, I describe the data and provide some preliminary graphical evidence. Section 5 discusses the statistical method, presents the relevant results, and includes placebo and robustness checks. I discuss the results in Section 6 and conclude Section 7.

\section{Literature}

My empirical analysis relates to the literature on the effects of changes in the statutory pension age on retirement behavior, and to the strand of empirical studies which investigate the substitution between social insurance programs. While most of the previous studies focused on single outcomes at a time, such as the retirement decision (Behaghel and Blau, 2012; Mastrobuoni, 2009; Manoli and Weber, 2016; Brinch et al., 2015) or on spillover effects on disability and unemployment programs (Autor and Duggan, 2003; Borghans et al., 2014; Staubli, 2011; Duggan et al., 2007; Inderbitzin et al., 2016), a growing literature is now turning attention to the impact of social security reforms on multiple outcomes that may catharize the exit route toward retirement. These outcomes not only include the employment and response to 
pension claims but also the program substitution toward other benefits and inactivity. Con $\urcorner$ sidering them jointly offers a more comprehensive and exhaustive understanding of the effects of a change in the set of social security rules. While several previous works assessed the effect of an increase of the ERA on multiple outcomes (Staubli and Zweimuller, 2013; Cribb et al., 2016; Geyer and Welteke, 2019; Atalay and Barrett, 2015; Soosaar et al., 2021), to the best of my knowledge, this study is the first to evaluate all of them together in response to a reform of the NRA.

Existing studies show that increases in pension-eligibility ages for both early and normal retirement are effective in increasing the employment rates of older individuals and delay pension claims (Behaghel and Blau, 2012; Staubli and Zweimuller, 2013; Atalay and Barrett, 2015'; Cribb et al., 2016; Manoli and Weber, 2016; Geyer and Welteke, 2019). However, on average the effect of an increase in ERA or NRA is smaller than what was established by law, due to alternative exit routes and competing incentives embedded in social security systems (Gruber and Wise, 1999). Manoli and Weber (2016), assessing the impact of a reform raising the ERA in Austria, estimate that, within a birth cohort, a one-year increase leads to a 0.4 -year increase in the average job exiting age and a 0.5 -year increase in the average pension claiming age. The magnitude of these effects is like that documented by Mastrobuoni (2009), who studies the effect of a U.S. reform raising the NRA adopting a difference-in-difference framework, and notes an increase in the average retirement age of about half as much as the increase promoted by the reform. Yet it is an empirical regularity that the spike in the benefit claiming hazard moves in lockstep along with the age of first eligibility for retirement benefits, since individuals tend to claim pension benefits as soon as possible (Behaghel and Blau, 2012; Gruber and Wise, 2007).

The existing evidence on the effects of increasing statutory pension age on the take-up of alternative benefits provide also quite comparable results, and most of the studies are based on a difference-in-differences identification strategy which exploits the exogenous variation in pensionable age induced by national policy interventions ${ }^{2}$. Staubli and Zweimüller (2013) and Atalay and Barrett (2015) find that gradual increases in the pension age led to program substitution, showing an increase of the inflow into unemployment benefit among Austrian men (Staubli and Zweimüller, 2013) and into disability support pension among women in Australia (Atalay and Barrett, 2015). Duggan et al. (2007) investigate the effect on the disability payroll of the 1983 U.S. Social Security reform, which increased by 2 years the NRA. They conclude that this restriction caused a remarkable program substitution accounting for around one-third of the disability growth experienced in the following years. In contrast, Geyer and Welteke (2019) and Oguzoglu et al. (2020), in evaluating the consequences of German and Australian pension reforms respectively, both imposing a raise of ERA for female employees, find no evidence of "active" program substitution. Although they also document a significant rise in unemployment and disability take-up rates, they show that these effects are mainly driven by a mechanical extension of the persistency in these labor market states rather than a net increase. Cribb et al. (2016) analyze women's reactions to a higher ERA in the UK and find a negligible increase

1 In reassessing the Australian pension reform, Morris (2021) finds that the employment response among women was considerably smaller than what was previously estimated by Atalay and Barrett (2015) and was almost negligible.

2 See Table 5 for a summary of previous research estimating the effect of raise of pensionable age on labor market outcomes, all adopting a research design similar to ours. 
in unemployment rates but a substantial increase in the probability of claiming a disability benefit (+44\%).

The reform under scrutiny in this paper has already been assessed previously by scholars who focused on different outcomes: retirement decision (Brugiavini and Peracchi, 2012), savings (Attanasio and Brugiavini, 2003), redistribution (Leombruni and Mosca, 2014), and financial incentives effects (Brugiavini et al., 2021). Regarding retirement decisions, Brugiavini and Peracchi (2012) documented that in the aftermath of the 1992 reform there was a remarkable increase in the inflow into early retirement options, arguably as a way to avoid future rises of early or NRA3. While the analysis of Brugiavini and Peracchi (2012) provided an extensive descriptive analysis of the effect of the 1992 reform on labor force participation and retirement transitions, they relied mainly on aggregate data comparing take-up rates before and after the year 1992. In contrast, the present analysis provides a counterfactual econometrics analysis, zooming into the different phases of the reform (which increased gradually the NRA over 10 years) and distinguishing between cohorts exposed to different treatment intensities. Furthermore, the present study assesses the heterogeneous impact of the reform estimating fully saturated and interacted DD models.

\section{Institutional Background}

The Italian National Institute for Social Security (INPS) provides insurance against the risks of old-age, death, health impairment, unemployment, maternity, and paternity and provides means-tested benefits for individuals and households in need. The INPS insures around 22.6 million among employees and self-employed individuals in the public and private sectors, corresponding to roughly $90 \%$ of the Italian workforce.

In the mid-1990s, social security expenditures accounted for around 17 per cent of GDP, and old-age and other public transfers corresponded to the largest share of household savings (Brugiavini, 1999). The old-age pension system was based on a mandatory public system covering most of the working population (just a few professional categories such as architects are covered only by their own professional funds) and was financed with a pay-as-you-go method. Occupational and private pension take-up was virtually zero during the nineties and they still play a marginal role even today (OECD, 2019) ${ }^{4}$.

The following sections give details on the pension rules (before and after the reform under study), the disability and unemployment benefit schemes for private-sector employees, which is the reference population in this paper. Finally, I provide a conceptual framework for interpreting the expected effects of the reform under study.

\subsection{The pension system before the 1992 reform}

At the time of the 1992 reform, the pension system was characterized by a defined benefit scheme, with a final benefit equal to the average of the last 5 years of gross earnings (the so-called pension base) times an accrual factor of $2 \%$ times the years of contributions (up to a

3 A similar "run" to the early-retirement option was observed also in France, Latvia, Slovakia, and Poland in response to national reforms of the pensionable age (Arpaia et al., 2009; European Commission, 2009).

4 Private pension-benefit expenditures represented only $6 \%$ of total pension spending in 2015 (OECD, 2019). 
maximum of 40 years), without any accrual correction for the age at retirement. Thus, a worker with 40 years of contributions would retire with a replacement rate of $80 \%$, which is quite a generous benefit. There existed two regular streams of access to a full pension benefit, which depended on the worker's age and the number of years of contributions accrued during the working life. Where the age qualification prevailed, it was called an "old-age pension", whereas where the contributions prevailed irrespective of age, it was called a "seniority pension".

The NRA for an old-age pension was 60 years for men and 55 years old for women, with at least 15 years of contributions. Alternatively, 35 years of contributions with no age limit for both men and women were required to be entitled to a seniority pension ${ }^{6}$. This dual-track system is common across Europe, where many countries offer the possibility to retire earlier than the NRA for persons having an extremely long insurance career, or who were exposed to arduous or hazardous working conditions ${ }^{7}$. Both old-age and seniority pension benefit amounts were calculated using the same defined benefit formula described above and without any accrual penalty for early claiming hence providing the same incentive to retire as soon as possible to workers with the same age and years of contributions (Brugiavini et al., 2021).

\subsection{The 1992 pension reform}

With the 1992 pension reform, the NRA and the years of contributions required for claiming an old-age pension were gradually increased for both men and women, starting from January 1994. This reform introduced a quasi-experimental variation in pensionable age between individuals depending on their birth date (Table 1), which I exploit in the empirical analysis.

Table 1 Eligibility conditions required for old-age pension as established by the 1992 Pension Reform (male private sector employees)

\begin{tabular}{lcc}
\hline Reference period & NRA & Contributions \\
\hline Before 1.1.1993 & 60 years old & 15 years \\
From 1.1.1993 to 31.12.1993 & 60 years old & 16 years \\
From 1.1.1994 to 31.12.1994 & 61 years old & 16 years \\
From 1.1.1995 to 30.6.1995 & 61 years old & 17 years \\
From 1.7.1995 to 31.12.1996 & 62 years old & 17 years \\
From 1.1.1997 to 30.6.1998 & 63 years old & 18 years \\
From 1.7.1998 to 31.12.1999 & 64 years old & 19 years \\
From 1.1.2000 to 31.12.2000 & 65 years old & 19 years \\
From 1.1.2001 to 30.6.2002 & 65 years old & 20 years \\
\hline
\end{tabular}

Notes: Author's elaboration based on ISTAT (2011, p. 80). The increase of the required contributions applies only to individuals with <15 years of contributions in December 1992. NRA, normal retirement age.

5 As from January 2012, the former Seniority pension (pensione di anzianità) has been replaced by an Early retirement pension (pensione anticipata) (DL 201/2011, n.24).

6 A third exceptional early retirement scheme (called "prepensionamento") was offered by the Government to workers' unions during the 80 s and 90 s to allow workers employed in firms facing financial constraints the possibility to claim a full pension benefit on relaxed eligibility conditions.

7 There is no single adopted definition of "arduous and hazardous jobs", however about two-thirds of European countries provide access to early retirement options based on the recognition that exposure to some conditions/occupations/ sectors is detrimental for health (Natali et al., 2016) and about half of European countries allow early retirement for workers with long contribution history (i.e. Austria, Belgium, Croatia, Czech Republic, Estonia, France, Germany, Greece, Latvia, Lithuania, Luxemburg, Malta, Poland, Portugal, Romania, Slovenia and Spain) (MISSOC, 2021). 
Figure 1 NRA by birth cohort as established by the 1992 Pension Reform.

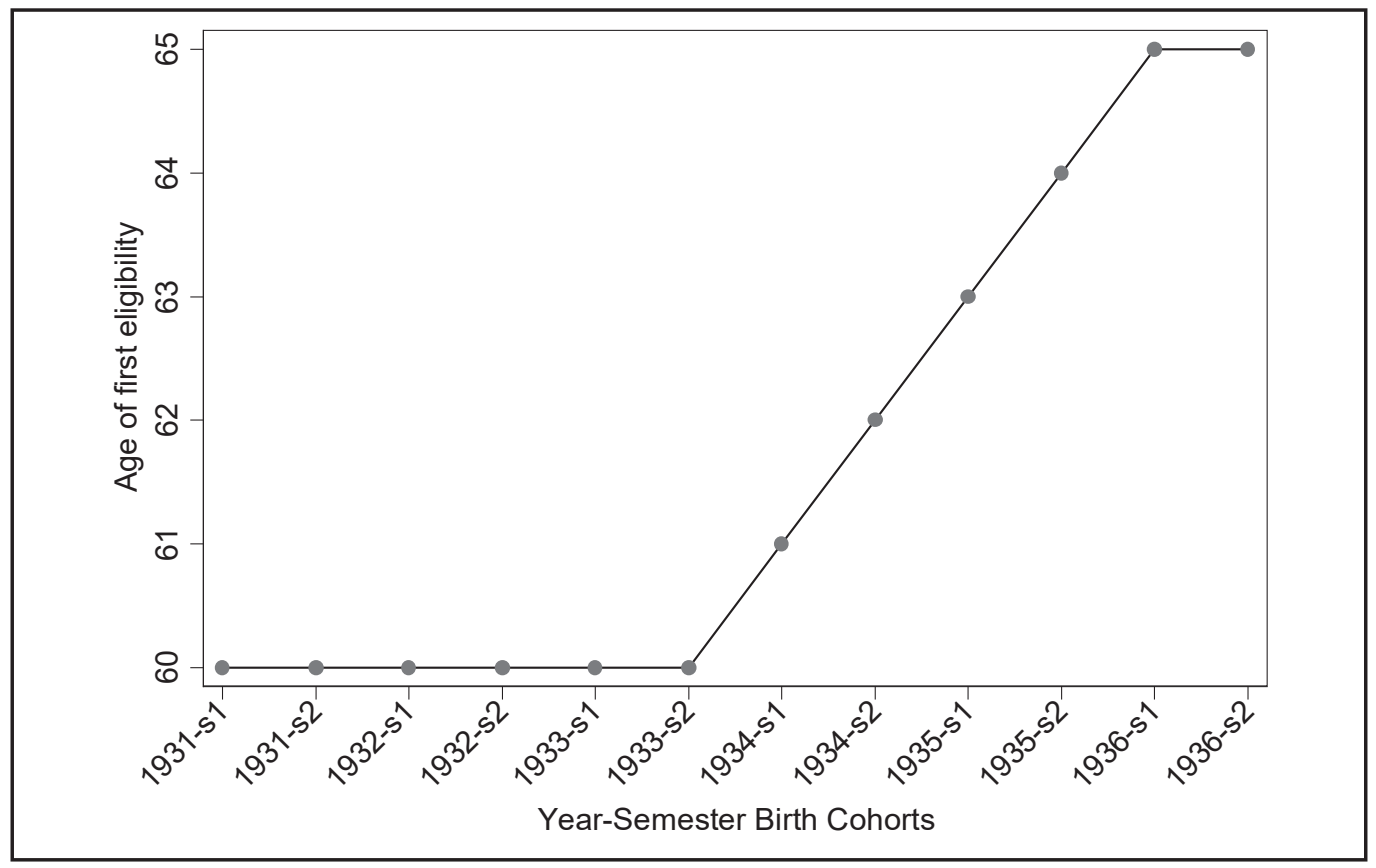

Source: Author's elaboration based on Table 1. NRA, normal retirement age.

Figure 1 plots the NRA faced by each cohort born between January 1931 and December 1936. This represents the reference population included in the empirical analysis. As can be noticed, while men born before January 1934 were unaffected by the reform, as they could retire at the age of 60 , workers born in the following years had to wait from 1 years to 5 years longer because of the NRA rise. These ages and cohorts' discontinuities are exactly the variation exploiting in the DD empirical analysis to identify the causal effect of the reform. In what follows, I will refer to the cohorts born in 1931-1933 as the "control" and to those born in 1934-1936 as the "treated" cohorts.

Together with the NRA, the 1992 reform also increased a) the years of contributions needed to access old-age pension from 15 years to 20 years for those with $<15$ years of contribution in $1992^{8}$ and b) the number of years of last salaries used to compute the pension base from 5 to 10 , maintaining the same defined benefit formula ${ }^{9}$. As discussed in more detail in Section 5.2 and Tables D4 and D5 in Appendix), these two other components of the reform had only very limited practical consequences for the cohorts included in my analysis.

In 1995, another pension reform was legislated, which changed both the eligibility rules for seniority pension and the calculation of old-age and seniority pension benefits based on a notional defined contribution system. The reform was characterized by a very long transition period and by a "grandfathering" approach aimed at protecting and preserving previous rules for older workers (Brugiavini et al., 2021), leaving the facto unaffected the cohorts included in our analysis ${ }^{10}$.

Hence, an important feature of the 1992 reform is that, while the NRA for claiming an oldage pension was raised by 5 years, the conditions to qualify for a seniority pension, i.e., 35 years

8 Article 2 of Law decree 503 of the 30th, December 1992.

9 Article 3 of Law decree 503 of the 30th, December 1992.

10 In particular, the 1995 reform changes the pension formula only for those with less than 18 years of contributions in 1995 ( $<1 \%$ of the estimation sample) and introduces a minimum age of 52 (than gradually increased) for claiming the seniority pension in 1996 (when individuals of my sample were already older than 60). 
of contributions with no age limit, remained unchanged. The seniority pension thus became a relatively more attractive option than the old-age pension to those individuals with long contribution histories, who, as shown by Brugiavini and Peracchi (2012), tended to react to the 1992 reform by anticipating the seniority pension claims to avoid the risk of future tightening of the eligibility conditions for the seniority pension, too. Since individuals with many years of paid contributions not only were in principle unaffected by the old-age pension reform (meeting already the eligibility condition for the seniority pension) but also tended to react to it by anticipating their labor market exit, they are excluded from the final sample of analysis.

\subsection{Unemployment and disability benefits}

In the years of the reform under scrutiny, there were three broad categories of unemployment schemes: an ordinary unemployment benefit, a short-time work scheme, and a long-term unemployment benefit, subject to a minimum number of paid contributions in the previous year and available only to some occupations/sectors of activity. The replacement rate varied between the different unemployment schemes, from $<10 \%$ to $80 \%$ and coverage was in general very limited. Although their availability and generosity increased with time, at the end of 2004 the majority of unemployed ( $>70 \%)$ were still unmet by any unemployment benefit schemes (Leombruni et al., 2012). More details on the evolution over time of the eligibility conditions and the replacement rate for every single benefit scheme are provided in Appendix B.

The social security system also granted different types of disability benefits to individuals unable to earn an income because of certified health conditions and whose work capacity was reduced by at least 66 per cent. The first kind was available to workers who had accrued at least 5 years of contributions, the benefit being calculated with the standard earning-related pension formula. The second type of benefit was not subject to previous work attachment and all persons could claim it, conditioning on the presence of the certified health-related work limitation. This benefit was means-tested, the amount set at $€ 279.47$ per month, topped up by $€ 512$ for assistance for those who need help to accomplish daily tasks (MISSOC, 2021).

\subsection{The expected effect of the reform}

Any reform of social security rules that increases NRA influences retirement choices according to dynamic life-cycle models where rational forward-looking individuals choose between labor and leisure to optimize the present value of the life stream of income sources from work and pension (e.g., Burtless and Moffitt, 1984; Gustman and Steinmeier, 1985).

The standard life cycle model provides an insightful framework for modeling retirement decisions, which helps to detail the expected effects of the reform. Following Blundell et al. (2016), there are three main effects induced by the pension reform under scrutiny here:

Pension wealth effects - Because the reform increased the NRA, i.e., the minimum age at which old-age pension can be claimed without introducing any accrual correction for the age at retirement, the reform can be interpreted as a negative wealth shock, as it reduces the length of time that individuals receive pension benefits and thereby the total social security wealth. Standard life cycle theory predicts that affected individuals decrease consumption, increase 
savings, increase labor supply, and the retirement age through the income effect (for example, Attanasio and Brugiavini, 2003).

Liquidity effects - Public pension benefits tend to be illiquid: that is, individuals cannot borrow against future benefits. This can induce liquidity constraints on individuals' behavior inducing them to retire at statutory retirement age (for example, Krueger and Pischke, 1992). This is particularly true in Italy, where public pension programs constitute a very large share of retirement savings and private pension had extremely limited diffusion (Brugiavini, 1999). As a result, I expect stronger labor supply effects and substitution toward unemployment and disability benefits for more liquidity-constrained individuals, who cannot finance their retirement until pension benefits become available. In contrast, the expected effect on inactivity is uncertain. More disadvantaged workers categories, who in general are more liquidity constrained, may not afford to retire without benefits but at the same time, they might be facing greater difficulties in remaining employed up to the new NRA.

Substitution effects - The operation of the tax, benefit, and pension rules, can affect the relative attractiveness of working vs. retirement. It has been shown that in Italy the pre-reform set of financial incentives implied a high implicit tax on work, which remained positive and significant even after the reform (Brugiavini et al., 2021), hence providing a strong incentive to retire as soon as the eligibility conditions for early or normal retirement are met. For the cohorts in analysis, substitution effects are expected to be stronger for workers who do not have the incentive to extend working life, having already reached "full contribution history" (i.e., those with 40 years of contributions - this subpopulation is excluded from my analysis) and low-skilled workers, because of a lower level of potential forgone earnings and perspective of future wage growth (Leombruni and Mosca, 2012).

ERA vs. NRA - Because the 1992 reform increased the NRA, the reduction in prospective pension wealth occurred relatively late in individuals' work lives. On theoretical grounds, a life-cycle theory predicts that a worker's reaction to benefit cuts will depend on when one first learns about the reform (Mastrobuoni, 2009). Hence, one would expect the 1992 reform to have a greater effect on pension claims and labor supply than a reform raising the ERA because there is less time for individuals to reoptimize and alter their savings and consumption plans. This reflects the fact that younger individuals have a longer horizon over which to absorb the "unexpected" shock to the pension wealth (Krueger and Pischke, 1992; Attanasio and Brugiavini, 2003).

Overall, these theoretical predictions suggest that the degree of adjustment in labor supply decisions after the reform may be influenced by several types of constraints, incentives, and information problems, particularly among older individuals. These factors can also give rise to substantial heterogeneities in adjustment behavior across population groups, which I have empirically tested in my analysis.

\section{Data and Descriptive Statistics}

\subsection{Data sources}

The empirical analysis is based on the Working Histories Italian Panel (WHIP), an administrative data set based on a 7\% random sample of the INPS archives (for more details on the 
WHIP data: Bena et al., 2012). The sample is representative of the population insured by the INPS, which is composed of non-agricultural private-sector workers. Only civil servants hired on an open-ended contract, some professional categories (e.g., lawyers, physicians, engineers, and architects), and workers without formal attachment to the labor market are excluded from the reference population.

The overall structure of WHIP builds upon a set of separate administrative archives covering jobs and various benefits spells. The archives are linked by means of a unique individual identifier and it is possible to construct the whole career of insured workers by tracking the starting and termination dates of the above-mentioned administrative spells $^{11}$.

The empirical analysis of this paper focuses only on the male population. This choice is motivated by the fact that in the years under analysis women experienced a striking positive trend in labor force participation rates ${ }^{12}$. This strong temporal heterogeneity in labor market attachment would pose a threat to a DD identification strategy based on the assumption of parallel trends between cohorts, which I have adopted for the current analysis.

The sample under analysis is composed of a set of control cohorts (born in 1931-1933) and treated cohorts (born in 1934-1936). Control cohorts consist of individuals who turned the age of 60 before the reform, i.e., reached the NRA for claiming an old-age pension before the increase established by the reform. In contrast, treated cohorts include individuals who were under 60 before the reform and consequently were affected by it (Figure 1). For every individual in the sample, I reconstructed the social security and work histories combining all employment and welfare benefits spells using as time unit the half-year (from now on, semester).

Since the paper aims to study the effect of the 1992 old-age pension reform on the transitions from work to retirement, the estimation sample includes only male workers who were in employment at 45-55 years old and who had regularly retired by the age of 67 years receiving any type of pension for private-sector employees (old-age, seniority, or early retirement). Moreover, I exclude men with $>35$ insurance years at 60 years old, as they are not affected by the increase in the NRA. The final dataset is a panel strictly balanced with respect to age and it includes 29,974 individuals from the age of 55-65 years old (659,428 observations).

Table 2 describes the final sample under analysis separately for the control and treated cohorts in terms of background characteristics, measured before the pre-reform NRA (panel A), and at pension receipt (panel B). Panel A shows that before the age of 60, control cohorts were marginally more likely to be still employed and to have worked in manual occupations. Annual earnings are higher among treated cohorts are more likely to retire through the seniority pension route (granting the right to full pension benefit at an ear $\neg$ lier age); they claim pension benefits 2.2 years later and accrued on average 1.7 more years of contributions.

11 For more details on the linking procedure, see Bena et al. (2012).

12 According to official national statistics (ISTAT), from 1986 to 2002 the employment rate was almost constant for men but raised by $24 \%$ for women. 
Table 2 Sample description

\begin{tabular}{|c|c|c|c|c|}
\hline & \multicolumn{2}{|c|}{ Control cohorts } & \multicolumn{2}{|c|}{ Treated cohorts } \\
\hline & Mean & St. Dev. & Mean & St. Dev. \\
\hline \multicolumn{5}{|c|}{ Panel A: Individuals characteristics at 55-59 years old } \\
\hline Employed (\%) & 75.7 & & 74.3 & \\
\hline \multicolumn{5}{|l|}{ Occupation (\%) } \\
\hline Manual & 75.4 & & 74.7 & \\
\hline Non-manual & 14.6 & & 16.1 & \\
\hline Manager & 0.4 & & 0.7 & \\
\hline Self-employed & 9.6 & & 8.5 & \\
\hline Sick-leave/work ratio ${ }^{a}$ & 0.3 & 0.90 & 0.3 & 0.92 \\
\hline Real annual earnings ${ }^{b}$ & 18,072 & 13,373 & 18,980 & 13,732 \\
\hline \multicolumn{5}{|c|}{ Panel B: Individuals characteristics at pension receipt } \\
\hline Years of accrued contributions & 25.2 & 7.73 & 26.9 & 8.14 \\
\hline \multicolumn{5}{|l|}{ Pension type } \\
\hline Seniority (\%) & 3.9 & & 20.3 & \\
\hline Old-age (\%) & 89.3 & & 76.4 & \\
\hline \multirow[t]{2}{*}{ Early retirement (\%) } & 6.8 & & 3.3 & \\
\hline & & 2.01 & & \\
\hline Pension claiming age & 60.1 & & 62.3 & 2.49 \\
\hline Individuals & 16,664 & & 13,310 & \\
\hline
\end{tabular}

Notes: Control and treated cohorts refer to individuals born in 1931-1933 and 1934-1936, respectively. ${ }^{a}$ Weeks of sick leave over weeks worked, measured at 58-59 years old. bEuro, 2005 prices.

\subsection{Outcomes definition}

The outcome variables are defined as a set of binary variables $Y_{i t j}$ taking value one if individual $i$ spent at least 1 month in semester $t$ in state $j$ (hence, the outcomes are not mutually exclusive) ${ }^{13}$. The $j$ labor market states are:

- Pension benefit: old-age, seniority, or early retirement pensions

- Employment: dependent employee, self-employment, and atypical contracts

- Unemployment benefit: Short-time work, ordinary and long-term unemployment benefits

- Disability benefit: disability benefit, civilian-invalidity benefit, and attendance allowance

- Inactivity: defined as a residual category for all the spells in which individuals are neither in employment nor receive any benefit

Since most unemployed individuals were not covered by unemployment benefits at the time under analysis (Leombruni et al., 2012), the category "Unemployment with benefit" is narrower than both statistical unemployment and registered unemployment ${ }^{14}$. Moreover, it

13 I have also explored the possibility of defining the outcomes as mutually exclusive prevalent economic states, but since results were qualitatively unaffected, I decided to stick on the first definition as it makes more efficient use of the data.

14 This is an Italian specificity, while for example, in Austria, registered unemployment figures are generally higher than statistical unemployment (Melis and Lüdeke, 2006). 
should be considered that the ordinary unemployment benefit had very limited diffusion up to 2005, being taken consequently only by treated cohorts. Finally, the residual category "Inactivity" does not actually include only inactive individuals, but also those working without a formal contract and the unemployed with no right to unemployment benefits. These labor market states can in any case be considered representative of a likely undesired labor market condition because they are characterized by limited rights and recognition. Additionally, periods of work spent on job contracts not covered by the data (such as open-ended contracts in the public sector) fall within this residual category, too. However, transitions back and forth to uncovered contracts at an older age are extremely rare, especially in my sample of retirees who qualified for a full pension benefit as private-sector employees (Contini, 2002).

Notice that, since the data lacks information on the entire firm population and on whether employment terminations are initiated by firms or by employees, it is not possible to disentangle between voluntary supply driven transitions out of paid employment from those that are instead demand driven, i.e., initiated by firms. Nevertheless, since entering inactivity in most cases leaves workers without any income or subsidy, transitions from employment to inactivity arguably represents an adverse and unforeseen outcome for older workers, which could be related to firms' behavioral reaction, particularly among low-income workers (Bovini and Paradisi, 2019).

\subsection{Graphical evidence}

Figure 2 plots the prevalence of each labor market outcome at every single age separately for the control cohorts, i.e., workers born in 1931-1933 who could all claim pension benefit at 60 years old, and treated cohorts, i.e., workers born after 1933 whose NRA was raised gradually up to 65 years by the 1992 reform.

The most common labor market states at 59 years old are employment, inactivity, and retirement with benefit, for $>95 \%$ of the individuals fall within one of these states at this age. After the age of 59, the pension benefit take-up rate (panel A) raises, displaying kinks corresponding to the age of first eligibility faced by different birth cohorts of workers, confirming the empirical regularity also observed in several other countries (Behaghel and Blau, 2012; Gruber and Wise, 2007). This series of parallel stepwise lines is the result of the gradual increase of NRA from 60 to 65 induced by the 1992 reform affecting different individuals born in different cohorts.

Panel B displays the age profile of the employment rate. Among the control cohorts (1931-1933) the probability of leaving employment follows a stepwise decrease, symmetrically to the inflow into retirement at 60 years old. Among treated cohorts, the pattern is similar but smoother for the youngest cohorts. For the 1935 and 1936 cohorts whose NRA was increased the most (to 64 and 65 years old), the early exit from employment (Panel B) seems to coexist with some anticipation of pension claiming at 62-63 (Panel A). Although the intensity of the treatment was higher for the 1935 and 1936 cohorts, they had relatively more time to adjust their behaviors and, arguably, they could "escape" the tightening of the old-age pension exit route exploiting the early retirement options.

Moving to the "Inactivity" and the "Disability benefit" outcomes (panels C and D), it is possible to observe a distinct parallel stepwise pattern, with a series of delayed kinks in correspondence of the eligibility ages. 
Figure 2 Labor Market Outcomes (\%) by age and birth cohorts.

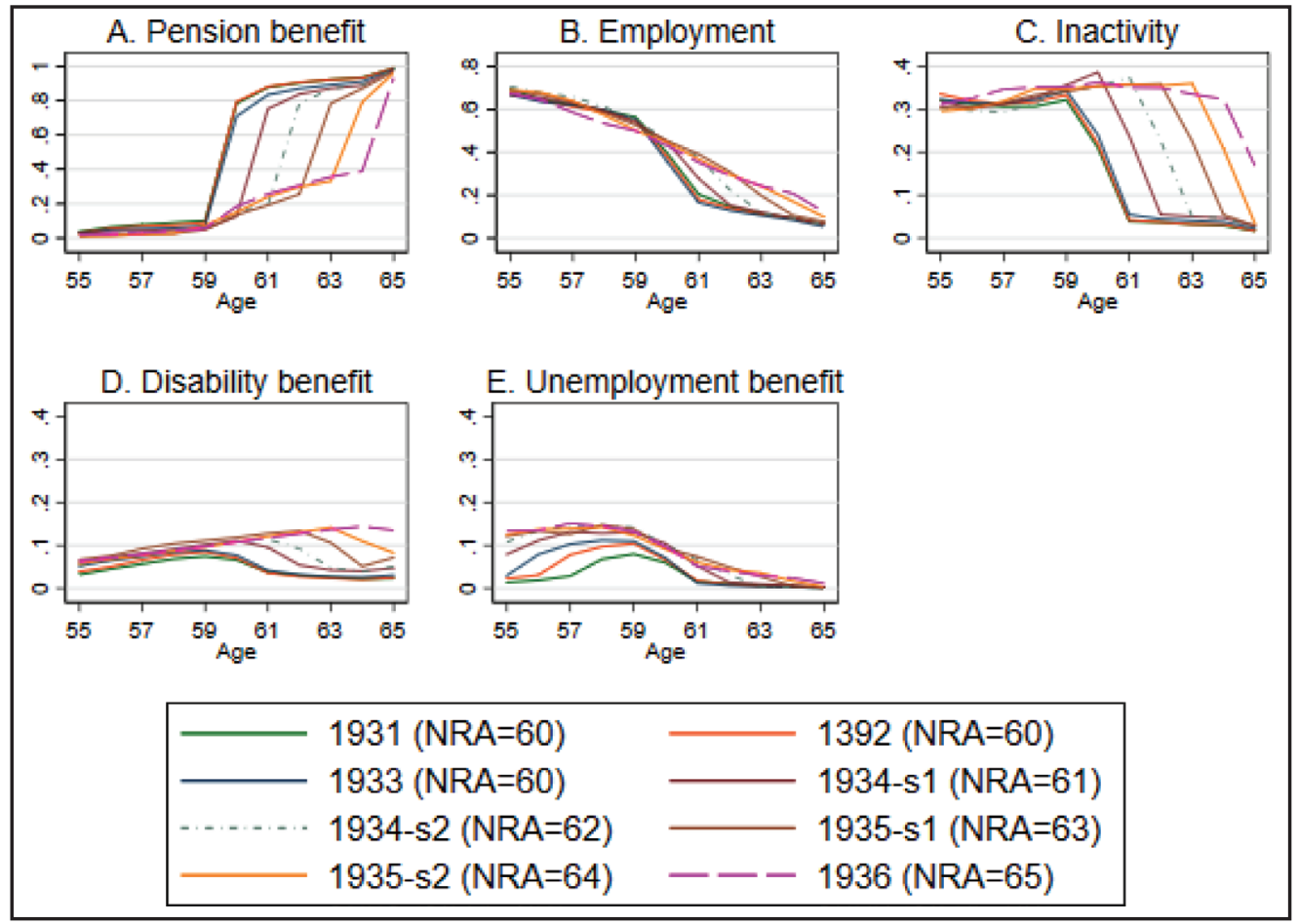

Notes: Proportion of persons in each labor market status by age and birth cohort. NRA, normal retirement age.

Eventually, panel E shows that the probability of being unemployed with benefit was higher among younger cohorts already before age 60 among the control cohorts born in 1931-1933. This pattern most likely depends on the gradual increase of the coverage and generosity of the benefits with time and on the fact that in the first half of the nineties, in the years 1992-1993, Italy experienced a worsening of economic conditions with a substantial rise of unemployment levels. I will deal with the presence of this and other possible common time shocks by saturating the difference-in-differences model with time-fixed effects and by running specific robustness tests (Tables D3 and D4 in Appendix). Moreover, the validity of the DD parallel trend assumption will be formally tested for all the outcomes separately in the following section (Figure 3).

\section{The Effect of NRA Increase}

\subsection{Methods}

To assess the effect of the rise in NRA, I adopt a DD strategy, exploiting the 1992 reform as a quasi-natural experiment. The staggered phase-in of the new NRA from 60 to 65 allows for comparison of the outcome levels between older and younger cohorts at the various steps of the tightening, using a standard approach exploited by previous studies on pension age reforms (Mastrobuoni, 2009; Staubli and Zweimuller, 2013, Cribb et al., 2016; Soosaar et al., 2021, Morris, 2021). With this DD set-up, the first difference is across cohorts: the cohorts are treated if born after 31 December 1933, whereas those born before that date were able to retire at the NRA of 60 under the pre-reform rules. The second difference is over age: treated ages are 60-64 as at these ages, treated cohorts became ineligible for old-age pension due to the rise 
of the NRA. However, since the NRA was raised gradually from 60 to 65 (Table 1), the reform did not affect all uniformly, as the post-reform cohorts had to wait from 1 to 5 additional years to become eligible for the old-age pension depending on their birth date (Figure 1). I take this point into account by building groups of treated and control cohorts that are age-specific, as shown in Table 3.

On this basis, to estimate the effect of the NRA rise, the primary approach is to compare the labor market behavior of untreated and treated cohorts at every single age, estimating the following DD regressions for each of the separate outcomes $Y_{i t}$ :

$$
Y_{i t}=\Sigma_{k \in\{55,56, \ldots, 65\})} \beta_{k} T_{a} * 1[a=k]+\gamma_{a}+\delta_{c}+\tau_{t}+\varepsilon_{i t}
$$

The above specification, where $i$ denotes individuals and $t$ denotes semesters, includes fixed effects for age $\left(\gamma_{a}\right)$ and birth cohort $\left(\delta_{c}\right)$. To control for the business cycle, also semester fixed effects are included $\left(\tau_{t}\right)$. Since age is measured in years (from 55 to 65 ) while birth cohorts and periods are measured in semesters (from 1931-s1 to 1936-s2 and from 1986-s1 to 2002-s1, respectively $)^{15}$, the model allows for the inclusion of a full set of fixed effects for each of the three dimensions without running into the perfect multi-collinearity trap (as also described in Hall et al., 2007 and done by Staubli and Zweimuller, 2013; Soosaar et al., 2021).

Equation (1) estimates a separate DD coefficient $\beta_{k}$ for the interaction between an indicator variable for the treatment group $T_{a}$ and every single age group $k$, which lends itself to a test for the common trend assumption in the spirit of Autor (2003). If treated cohorts showed trends parallel to the control cohorts in the outcomes even in the absence of the reform, I should observe no significant difference in the take-up of the outcomes in the "placebo ages", i.e., in all the ages before 60 (because the reform did not modify the eligibility conditions for these ages) or after 64 (because at 65 everyone was entitled to an old-age pension). The results from this specification are displayed in Figure 3.

To obtain an average effect of the reform over the entire set of treated ages, and to adhere more closely to previous literature, I also estimate the following equation:

$$
Y_{i t}=\beta * 1_{t}[a<N R A]+\gamma_{a}+\delta_{c}+\tau_{t}+\varepsilon_{i t}
$$

As in Staubli and Zweimüller (2013), Cribb et al. (2016), Soosaar et al. (2021), and Morris (2021), the set of interactions terms is replaced by a single indicator $1_{t}[a<N R A]$ that takes on value one if the individual age in semester $t$ is below the regulated NRA. This variable captures the treatment of ineligibility for an old-age pension, which results from the interaction between treatment levels (i.e., ages) and groups (i.e., birth cohorts) and which varies over time because of the gradual increase of the NRA. The DD estimator $\beta$ measures the average difference in mean outcomes between control and treated cohorts in treated ages (60-64 years old) minus the control and treated cohorts' differences in mean outcomes for the untreated ages (before 60 and $>64$ ). Table $\mathrm{C} 1$ in the appendix shows what the treated and untreated calendar years and ages are for the cohorts under study, i.e., 1933 to 1936. The specification includes, as in previous studies adopting this approach ${ }^{16}$, cohorts, age, and period fixed effects. The same considerations regarding the perfect multi-collinearity trap made for Eq. (1) apply here, too.

15 The categories of age, cohorts and periods are shown in Table B1.

16 See for example Staubli and Zweimuller (2013) Page 25, Table 3, columns (2)-(4) and (6)-(8). 
Table 3 Treated and control groups definition by age and year of birth

\begin{tabular}{|c|c|c|c|}
\hline Age & $\begin{array}{l}\text { Control group } \\
\left(T_{a}=0\right)\end{array}$ & $\begin{array}{l}\text { Treated group } \\
\left(T_{a}=1\right)\end{array}$ & Eligibility to NRA \\
\hline From 55 to 59 & $1931-1933$ & $(1934-1936)$ & Placebo ages: no one is eligible \\
\hline 60 years old & 1931-1933 & $1934-1936$ & Only the control group is eligible \\
\hline 61 years old & 1931-Jun 1934 & Jul 1934-1936 & Only the control group is eligible \\
\hline 62 years old & 1931-Dec 1934 & 1935-1936 & Only the control group is eligible \\
\hline 63 years old & 1931-Jun 1935 & Jul 1935-1936 & Only the control group is eligible \\
\hline 64 years old & 1931-Dec 1935 & 1936 & Only the control group is eligible \\
\hline 65 years old & 1931-1933 & $(1934-1936)$ & Placebo age: everyone is eligible \\
\hline
\end{tabular}

Notes: Author's elaboration based on Table 1. NRA, normal retirement age.

Some methodological issues left unmet by previous works using my same DD specification to study the effect of similar pension age reforms need to be stressed. First, since the main source of policy variation occurs at time and cohort levels, the standard errors should be clustered at these levels, accounting for 33 or 12 clusters, respectively. However, Bertrand et al. (2004) and Cameron et al. (2008) have stressed that conventional DD clustered standard errors may understate the true standard deviation in samples with $<50$ clusters. Hence, following their suggestion, I adopt the wild bootstrap (WB) technique to compute the clustered standard errors. Second, to avoid the problem of inflation of alpha level which can originate from testing multiple outcomes (the larger the number of tests, the higher is the chance to encounter a rare event and to conclude that there is a significant effect when there is none), I correct $p$-values using the Šidàk multiple hypothesis correction formula $1-(1-p)^{n}$ where $p$ is the original $p$-value and $n$ the number of outcomes of the hypothesis tested (Abdi, 2007) ${ }^{17}$.

As pointed out by de Chaisemartin and D'Haultfoeuille, 2020a, b; Baker et al., 2021, in a staggered DD design like the one adopted here, the estimated DD coefficients is a weighted sum of several DD with potentially negative weights, since the outcome evolution is compared between consecutive time periods across treated and control groups whose composition varies with time (de Chaisemartin and D'Haultfoeuille, 2020a, b). Whenever the number of negative weights is high and there is treatment effect heterogeneity, the weighted average represented by the final DD coefficient might be biased and the sign of the estimated beta even reversed (de Chaisemartin and D'Haultfoeuille, 2020a, b). In Section 5.2, I present the results derived from estimating the two-way fixed effect estimators developed by de Chaisemartin and D'Haultfoeuille (2020a, b), which explicitly accounts for the problem of negative weighting, and it is robust even in the presence of treatment effect heterogeneity across groups or time. ${ }^{18}$

\section{Results}

Figure 3 displays the DD coefficients obtained by running Eq. (1) using wild bootstrap 95\% confidence intervals with the Šidàk correction for multiple hypotheses. They capture the mean

17 The wild bootstrap and Šidàk multiple hypothesis correction are implemented using the Stata macro developed by Roodman et al. (2019).

18 The two-way fixed effect estimator is implemented using the Stata command "did_multiplegt" developed by Chaisemartin and D'Haultfoeuille (2020a) with the dynamic option (Chaisemartin and D'Haultfoeuille, 2020b). 
Figure 3 Effect of raising the NRA on different labor market outcomes at every single age (Ages before, during, and after the NRA rise).

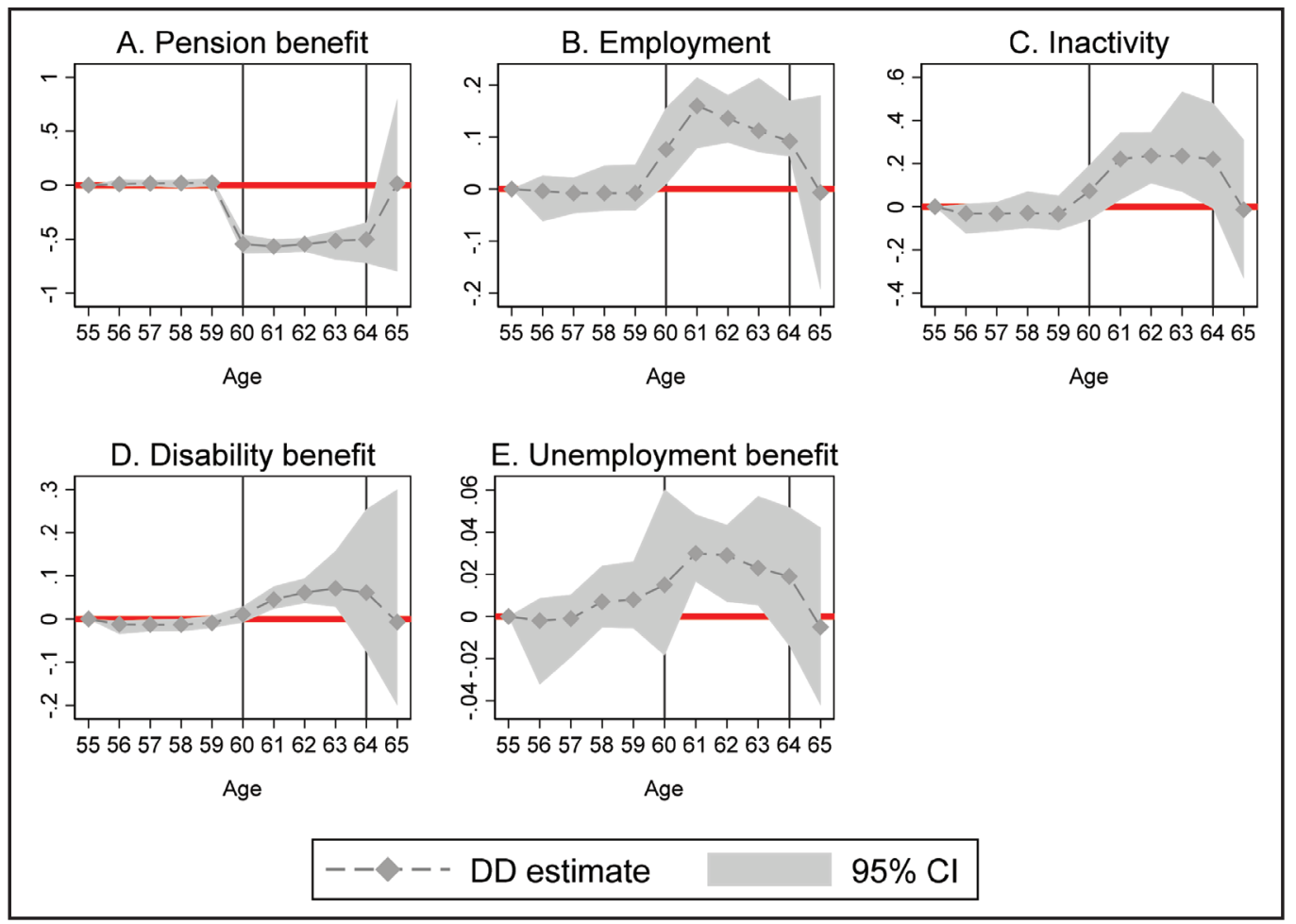

Notes: The figure displays the estimated DD coefficient $\beta$ (Eq. 1) and $95 \% \mathrm{Cl}$ separately for each of the outcomes. $95 \% \mathrm{Cl}$ are computed as a wild bootstrap percentile interval, thus they might be not centered around the point estimate. WB procedure with 999 repetitions. Šidàk correction for 11 multiple hypotheses. Vertical lines indicate the first (60) and last (64) treated age by the reform increasing NRA. Full output is available in Table C1 in Appendix. DD, difference-in-differences; NRA, normal retirement age; WB, wild-cluster bootstrap.

difference between treated and control cohorts at every single age from the 56th to the 65th birthday net of the difference at 55 years old. For the first four of the five labor market outcomes, the point estimates fluctuate around zero before the age of 60 and at the age of 65 , i.e., the placebo ages, while they are significantly different from zero in the ages actually treated by the reform. This provides strong support to the common trend assumption, confirming that the DD estimator is not picking up long-run trends in differences between younger and older cohorts, but it is instead driven by the effect of the NRA rise.

As can be noticed, the NRA raise leads to a substantial reduction in the take-up of pension benefit (panel A), and a contemporaneous increase in the employment rate (panel B). Moreover, inactivity, disability and, to a lesser extent, unemployment also grow among the treated cohorts in response to the tightening of the NRA (panel C-E). However, for unemployment it is possible to detect some evidence of a pre-trend between treated and control cohorts, as the DD coefficients, despite being not significantly different from zero before age of 60, show an increasing take-up among treated cohorts, confirming some of the concerns raised in the descriptive section.

Table 4 shows the results of Eq. (2) estimating the average effect of rising NRA following the approach of Staubli and Zweimüller (2013). The panel A reports the estimated DD coefficient associated with the indicator $1_{t}[a<N R A]$ and $p$-values obtained using wild bootstrap with 
Table 4 Effect of raising the NRA on different labor market outcomes

\begin{tabular}{|c|c|c|c|c|c|}
\hline & $\begin{array}{l}\text { Pension } \\
\text { benefit }\end{array}$ & Employment & Inactivity & $\begin{array}{c}\text { Disability } \\
\text { benefit }\end{array}$ & $\begin{array}{c}\text { Unemployment } \\
\text { benefit }\end{array}$ \\
\hline \multicolumn{6}{|c|}{ Panel A: Standard DD estimator } \\
\hline Age $<$ NRA & $-0.440^{\star \star \star}$ & $0.087^{\star \star \star}$ & $0.134^{\star \star \star}$ & $0.042^{\star \star \star}$ & 0.016 \\
\hline WP $p$-value & 0.000 & 0.000 & 0.000 & 0.000 & 0.045 \\
\hline WB Šidàk $p$-value & 0.000 & 0.000 & 0.000 & 0.000 & 0.206 \\
\hline$\overline{A d j .} R^{2}$ & 0.87 & 0.18 & 0.08 & 0.04 & 0.02 \\
\hline Observations & 659,428 & 659,428 & 659,428 & 659,428 & 659,428 \\
\hline Pre-reform mean & 0.92 & 0.12 & 0.05 & 0.02 & 0.01 \\
\hline$\%$ change & $-51 \%$ & $+48 \%$ & $+178 \%$ & $+111 \%$ & n.s. \\
\hline \multicolumn{6}{|c|}{ Panel B: De Chaisemartin and D'Haultfoeuille (2020b) DD estimator } \\
\hline Age $<$ NRA & $-0.552^{\star \star \star}$ & $0.090 * \star \star$ & 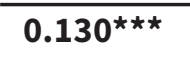 & $0.025^{\star \star \star}$ & 0.003 \\
\hline WB SE & 0.016 & 0.008 & 0.005 & 0.002 & 0.005 \\
\hline
\end{tabular}

Notes: The table displays the estimated DD coefficient $\beta$ (Eq. 2) separately for each of the outcomes (columns). SE clustered at period level. WB procedure with 999 repetitions. Šidàk correction for five multiple hypotheses. \% Change computed for coefficients significantly different from 0 with respect to pre-reform means (control cohorts at 60-64 years old). Significance based on WB p-value: ${ }^{\star \star \star} 1 \%,{ }^{\star \star} 5 \%,{ }^{\star} 10 \%$ (with Šidàk correction in Panel A). Full output is available in Table C2 in Appendix. DD, difference-in-differences; NRA, normal retirement age; WB, wild-cluster bootstrap.

and without the correction for multiple hypotheses. The full results are provided in appendix B (Table B3 in Appendix). The coefficients (if multiplied by 100) indicate by how many percentage points a person whose age is below NRA - i.e., noneligible to claim an old-age pension - is more or less likely to be drawing a pension, employed, unemployed, etc. with respect to a person who at the same age, before the reform, was eligible for an old-age pension. This marginal effect is estimated conditioning on the effects of the business cycle and individual characteristics. In practice, it provides an average of the several DD effects of becoming non-eligible at 60, 61, 62, 63 , and 64 years because of the NRA rise.

The results, displayed in Table 4 panel A, are consistent with what emerged from the graphical inspections of Figure 3. The 1992 pension reform, by establishing a higher NRA for claiming an old-age pension, succeeds in reducing the inflow into normal retirement and in increasing employment levels among older workers. Among treated individuals, the probability of claiming a pension drops by 44 percentage points, and the employment level increases by 9 percentage points. The most remarkable result to emerge from the data is that inactivity, covering all those who retired or became unemployed without any benefit, increases more than employment, both in absolute and in relative terms, among the treated cohorts. Becoming ineligible because of the tightening of the NRA also impacts considerably on the disability take-up rate, which doubled its pre-reform levels. In turn, both the size and significance of the unemployment benefit coefficient suggest a negligible effect.

In panel B, I report the results obtained using the two-way fixed effect estimator developed by de Chaisemartin and D'Haultfoeuille (2020b). This estimator is unbiased even in the case of staggered fuzzy DD design with heterogenous treatment across units and time, in which the composition of treated and control groups evolves together with the reform. The results 
are very similar to the baseline estimates (panel A), both qualitatively and quantitatively. The only noticeable difference in the estimates is given by the coefficient associated with the disability benefit take-up rate, which appears to be smaller in size but still positive and significant. Overall, this analysis suggests that in this context, if any, the bias deriving from the dynamic composition of treated and control groups was negligible.

In Table D1 and D2 in Appendix, I also show that the estimates remain almost identical if I include individual fixed effects and very similar if I remove periods fixed effects in Eq. (2). Specifically, when I remove time fixed effects the estimates are like the baseline estimates for all the outcomes but for the unemployment, for which the estimated DD becomes negative but only marginally significant (at 10\% significance level). This seems reasonable and coherent with what emerged in the descriptive analysis, where I showed that treated cohorts were experiencing some trend toward higher unemployment rate already before the age of 60 , possibly because of the crisis hitting the Italian economy in the 1992-1993 and because unemployment benefit schemes became more generous and largely available during the 1990s. By removing time fixed effects, the specification does not control any more for time shock common to the different cohorts and allows $\beta$ to capture not only the differences in outcome rates across treated and untreated cohorts stemming from the reform effects, but also from business cycle and the introduction of other institutional features.

The results seem to confirm that including period dummies in Eq. (2) is indeed important for controlling for the potential effect of the economic cycle, which indeed had a differential effect on cohorts above and below the NRA. To further investigate whether the 1992-1993 crisis influences the results, I check the robustness of the main findings by dropping the years 1992-1993 and show that estimates remain quantitively very similar to the baseline (Table D3 in Appendix). Soosaar et al. (2021) use a similar approach to investigate whether the 2009-2011 financial crisis might be driving their results in their evaluation of the effects of the Estonian pension age reform.

I also assess the robustness of the results to concerns related to potential interaction with other pension reform components. The Italian 1992 reform not only increased the NRA but also changed the pension benefit formula by extending the years to be used for the computation of the pension base and the minimum years of contribution (see Section 3.2). Hence, a possible concern is that the treatment effect comprises not only the effect of an increase in NRA but also that of these other two pension reform components. However, the long transition period for their implementation left almost unaffected individuals included in the sample, hence the threat to the identification strategy is arguably negligible. In fact, the change to the contribution requirement only involves individuals with $<15$ years of contribution in 1992 , i.e., $<1 \%$ of my sample (results are robust to the exclusion, as shown in Table D4 in Appendix). Similarly, the change in the pension base formula took place gradually over 10 years resulting in a very smooth transition period with no cohorts' discontinuities and small economic impact on the pension base (Table D5 in Appendix).

Finally, since the 1992 reform only changes the eligibility rules for the old-age pension, I show in Table D6 in Appendix that, when I separate the probability of drawing old-age pension from the seniority and early retirement pensions, reassuringly the estimated effect is entirely borne by the change in the inflow into an old-age pension, while the inflow into early retirement schemes is null. 


\subsection{Heterogeneity analysis}

This section describes how the impact of a rise in NRA varies between individuals with different socio-economic backgrounds. To do so, I first estimate Eq. (2) separately for different subgroups of the sample of analysis (Table 5) and then perform a fully saturated model with the simultaneous interaction of the indicator variable $1_{t}[a<N R A]$ with several indicators of socioeconomic position measured at 55-59 years old (Table 6). The full regression outputs are presented in Table C3 in Appendix.

The first subsample analysis in Table 5 aims to investigate the presence of a potential mechanism which might be driving the results, i.e., "persistency" into pre-reform labor market states resulting in passive - rather than active - program substitution. In fact, as suggested by Geyer and Welteke (2019), an observed increase, for example, in disability benefit take-up, could result from both a higher number of persons actively changing from employment to disability, or a higher proportion of persons simply staying longer in this status. Hence, I restrict the sample to those continuously employed and who never received benefits at 55-59 years old and show that the estimated effects of the NRA rise are very close to those obtained on the full sample, suggesting that the main results are not driven by "passive program substitution". In the following rows, I compute the effect of raising the NRA on different groups, restricting the focus on continuously employed before 60 years old to avoid the potentially differential interference of passive program substitution.

For all the socio-economic dimensions analyzed in Table 5 (occupational grade, wage, and health), the effect of the reform is larger in the most disadvantaged subsamples, i.e., with low wage (the poorest tertile), employed as manual workers, and with poor health (with $>1$ month of sick leave per year of work, corresponding to the third tertile of the distribution of weeks of sick leave). In particular, the pension benefit reduction among workers with the lowest salary and occupational grade is roughly around twice the reduction observed among those with the highest salary and occupational grade. Interestingly, the subsample of executives resulted almost unaffected by the NRA increase.

Table 5 Heterogeneous effect of rising the NRA: subsample analysis

\begin{tabular}{|c|c|c|c|c|c|c|}
\hline & $\begin{array}{l}\text { Pension } \\
\text { benefit }\end{array}$ & Employment & Inactivity & $\begin{array}{c}\text { Disability } \\
\text { benefit }\end{array}$ & $\begin{array}{c}\text { Unemployment } \\
\text { benefit }\end{array}$ & Obs. \\
\hline Full sample & $-0.440^{\star \star \star}$ & $0.087^{\star \star \star}$ & $0.134^{\star \star \star}$ & $0.042^{\star \star \star}$ & 0.016 & 659,428 \\
\hline Always employed bef. 60 & $-0.384^{\star \star \star}$ & $0.092^{\star \star \star}$ & $0.089^{\star \star \star}$ & $0.034^{\star \star \star}$ & $0.029^{\star}$ & 413,107 \\
\hline Low Wage $\left(1^{\circ}\right.$ tertile $)$ & $-0.459^{\star \star \star}$ & $0.071^{\star \star \star}$ & $0.148^{\star \star \star}$ & $0.045^{\star \star \star}$ & $0.022^{\star \star}$ & 135,377 \\
\hline High wage ( $3^{\circ}$ tertile) & $-0.271^{\star \star \star}$ & $0.075^{\star \star \star}$ & $0.043^{\star \star \star}$ & $0.017^{\star \star \star}$ & $0.022^{\star}$ & 135,377 \\
\hline Low occ. Grade (manual) & $-0.414^{\star \star \star}$ & $0.107^{\star \star \star}$ & $0.094^{\star \star \star}$ & $0.041^{\star \star \star}$ & $0.034^{\star}$ & 299,774 \\
\hline High occ. Grade (execut.) & -0.186 & 0.057 & 0.067 & na & -0.003 & 2,377 \\
\hline Low health ( $1^{\circ}$ tertile $)$ & $-0.423^{\star \star \star}$ & $0.098^{\star}$ & $0.064^{\star \star \star}$ & $0.078^{\star \star \star}$ & $0.040^{*}$ & 85,086 \\
\hline Good health ( $3^{\circ}$ tertile) & $-0.377^{\star \star \star}$ & $0.081^{\star \star \star}$ & $0.109^{\star \star \star}$ & $0.015^{\star \star \star}$ & $0.014^{\star}$ & 255,327 \\
\hline
\end{tabular}

Notes: The table displays the estimated DD coefficient $\beta$ (Eq. 2) obtained from separate split sample analyses (rows) for each of the outcomes (columns). SE clustered at period level. WB procedure with 999 repetitions. Šidàk correction for five multiple hypotheses. Significance based on WB Šidàk p-value: ${ }^{\star \star \star} 1 \%,{ }^{\star \star} 5 \%$, ${ }^{\star} 10 \%$. DD, difference-in-differences; NRA, normal retirement age; WB, wild-cluster bootstrap. 
Table 6 Heterogeneous effect of rising the NRA: fully interacted analysis

\begin{tabular}{|c|c|c|c|c|c|}
\hline & $\begin{array}{l}\text { Pension } \\
\text { benefit }\end{array}$ & Employment & Inactivity & $\begin{array}{c}\text { Disability } \\
\text { Benefit }\end{array}$ & $\begin{array}{c}\text { Unemployment } \\
\text { benefit }\end{array}$ \\
\hline Age $<$ NRA (Ref. category ${ }^{a}$ ) & $-0.167^{\star \star \star}$ & 0.006 & -0.021 & $0.037^{\star \star \star}$ & $0.025^{\star \star \star}$ \\
\hline$\overline{\text { Age }<\text { NRA } \times \text { Low wage }}$ & $-0.092^{\star \star \star}$ & 0.004 & $0.056+$ & -0.011 & 0.000 \\
\hline WB p-value & 0.000 & 0.871 & 0.031 & 0.081 & 0.955 \\
\hline WB Šidàk p-value & 0.000 & 1.000 & 0.451 & 0.288 & 1.000 \\
\hline Age $<$ NRA $\times$ Mid wage & $-0.052^{\star \star \star}$ & $0.022^{\star \star}$ & 0.009 & 0.000 & 0.003 \\
\hline WB p-value & 0.000 & 0.005 & 0.070 & 0.957 & 0.546 \\
\hline WB Šidàk p-value & 0.000 & 0.024 & 0.341 & 1.000 & 0.986 \\
\hline Age $<$ NRA $\times$ Low occ. grade & $-0.18^{\star \star}$ & $0.089+$ & $0.097^{\star \star}$ & -0.006 & 0.003 \\
\hline WB p-value & 0.001 & 0.025 & 0.004 & 0.152 & 0.524 \\
\hline WB Šidàk p-value & 0.012 & 0.242 & 0.012 & 0.545 & 0.990 \\
\hline Age $<$ NRA $\times$ Mid occ. grade & $-0.108+$ & 0.008 & $0.085^{\star}$ & 0.001 & 0.006 \\
\hline WB p-value & 0.011 & 0.827 & 0.007 & 0.629 & 0.115 \\
\hline WB Šidàk p-value & 0.130 & 1.000 & 0.064 & 0.999 & 0.561 \\
\hline Age $<$ NRA $\times$ Low health & $-0.025^{\star}$ & $0.024^{\star \star}$ & -0.011 & $0.020+$ & 0.007 \\
\hline WB p-value & 0.013 & 0.003 & 0.131 & 0.017 & 0.240 \\
\hline WB Šidàk p-value & 0.081 & 0.036 & 0.615 & 0.256 & 0.824 \\
\hline Age $<$ NRA $\times$ Mid health & 0.005 & 0.008 & -0.014 & 0.005 & -0.004 \\
\hline WB $p$-value & 0.645 & 0.359 & 0.120 & 0.056 & 0.564 \\
\hline WB Šidàk p-value & 0.998 & 0.921 & 0.647 & 0.390 & 0.991 \\
\hline Adj. $R^{2}$ & 0.689 & 0.62 & 0.15 & 0.055 & 0.069 \\
\hline Observations & 371,622 & 371,622 & 371,622 & 371,622 & 371,622 \\
\hline
\end{tabular}

Notes: The table displays the estimated DD coefficient $\beta$ of Equation (2) interacted simultaneously with different socio-economic group indicators separately for each of the outcomes (columns). a Ref. category composed of the three excluded categories: workers with high wage, high occupational grade (executives) and good health. SE clustered at period level. WB procedure with 999 repetitions. Šidàk correction for six multiple hypotheses. Significance based on WB Šidàk p-value: ${ }^{\star \star \star} 1 \%,{ }^{\star \star} 5 \%,{ }^{\star} 10 \%$. In addition, coefficients with WB p-value $<5 \%$ are marked with +. Full output is available in Table B3 in Appendix. DD, difference-in-differences; NRA, normal retirement age; WB, wild-cluster bootstrap.

Since this pattern might be driven by omitted variable bias, given that these characteristics are likely to coexist (manual workers have generally lower salaries and poorer health than executives), I expand Eq. (2) and estimate a fully saturated DD model which simultaneously interacts all these socio-economic conditions with the treatment DD variable $1_{t}[a<N R A]$. Table 6 presents the results. Despite the model being quite demanding and the stringent values of alpha imposed by the Šidàk's method, the heterogeneous effect of raising the NRA is confirmed. A rise in the NRA causes the largest reduction on workers with the lowest wage, occupational grade, and health and an intermediate reduction among those with the mid occupational grade, wage, and health, suggesting the presence of a clear socio-economic gradient: the greater the disadvantage, the greater the delay of pension claiming and the labor supply response.

Among more advantaged categories pension claiming drop was mild, and I detect a null effect on employment and inactivity rates. In contrast, the inactivity rate increased substantially 
among workers with low wages and low occupational grades, for whom the increase of inactivity exceeds the employment response.

Not much heterogeneity survives on the disability and unemployment outcomes, apart from a marginally significant higher risk of taking up disability pension benefits for people with poorer health. However, there is the possibility that I could not detect significant heterogeneous effects on these outcomes due to lack of power, since a very small proportion of individuals take up the two benefits.

A possible concern is that the characteristics used in this analysis are endogenous since they are measured at 55-59 years old, i.e., partly in the post-1992 years for the treated cohorts. However, if I measure characteristics only at 55 years and use information coming entirely from the pre-1992 period (at the expense of losing the possibility of having sick leave among the variables), the estimated effects are quantitatively the same for all the outcomes and the overall pattern is largely confirmed. Results are shown in Table D7 in Appendix.

\section{Discussion}

Overall, the results of my analysis are in line with previous studies that applied a similar research design to assess the effect of reforms raising pension age (Table 7).

As occurred in Australia, Austria, Germany, France, and the UK, the increase in the pensionable age significantly delayed pension benefit claims. Moreover, these types of reforms have to a lesser extent increased employment levels and induced substitution toward alternative welfare programs, and higher inactivity rates among older workers.

Table 7 Effect of rising ERA/NRA on different labor market outcomes: comparison of previous studies

\begin{tabular}{|c|c|c|c|c|c|}
\hline & $\begin{array}{l}\text { Retirement } \\
\text { benefit }\end{array}$ & Employment & $\begin{array}{l}\text { Disability } \\
\text { benefit }\end{array}$ & $\begin{array}{l}\text { Unempl. } \\
\text { benefit }\end{array}$ & Inactivity \\
\hline $\begin{array}{l}\text { IT (m, NRA 60-65) } \\
\text { (My results, Table 4) }\end{array}$ & $-0.44^{\star \star \star}$ & $0.087^{\star \star \star}$ & $0.042^{\star \star \star}$ & 0.016 & $0.134^{\star \star \star}$ \\
\hline $\begin{array}{l}\text { AUT (f, NRA 60-64.5) } \\
\text { Oguzoglu et al., } 2020 \\
\text { (Table 2) }\end{array}$ & $-0.519^{\star \star \star}$ & na & $0.143^{\star \star \star}$ & $0.039^{\star \star \star}$ & na \\
\hline $\begin{array}{l}\text { AUS (m, ERA 60-62) } \\
\text { Staubli and Zweimuller, } \\
2013 \text { (Table 3) }\end{array}$ & $-0.248^{\star \star \star}$ & $0.097^{\star \star \star}$ & $0.010^{\star \star \star}$ & $0.125^{\star \star \star}$ & $0.016^{\star \star \star}$ \\
\hline $\begin{array}{l}\text { GER (f, ERA, 60-62) } \\
\text { Geyer and Welteke, } 2021 \\
\text { (Table 1) }\end{array}$ & $-0.276^{\star \star \star}$ & $0.135^{\star \star \star}$ & -0.007 & $0.052^{\star \star \star}$ & $0.062^{\star \star \star}$ \\
\hline $\begin{array}{l}\text { FRA (all, ERA 60-61) } \\
\text { Rabaté and Rochut, } 2020 \\
\text { (Table 5) }\end{array}$ & $-0.478^{\star \star \star}$ & $0.209^{\star \star \star}$ & $0.059^{\star \star \star}$ & $0.134^{\star \star \star}$ & $0.062^{\star \star \star}$ \\
\hline $\begin{array}{l}\text { UK (f, ERA 60-62) } \\
\text { Cribb et al., 2016 } \\
\text { (Tables } 4 \text { and 5) }\end{array}$ & $-0.115^{\star \star \star}$ & $0.063^{\star \star}$ & $0.040^{\star \star \star}$ & $0.012^{\star \star \star}$ & 0.008 \\
\hline
\end{tabular}

Source: Author's elaboration.

ERA, early retirement age; NRA, normal retirement age. 
In my study, the magnitude of the pension claiming drop and of the increased inflow into inactivity were more marked, while the employment response was slightly milder, than what has been documented in previous studies. The large effect on pension drawing is likely due to the strong incentive to retire exactly at the NRA, given the absence of any penalty on early claiming in Italy (Brugiavini et al., 2021). Moreover, two demographic factors arguably contribute to these results too: age and gender. In previous studies, the target population is composed of women, who generally display higher labor supply elasticity than men (Evers et al., 2008). Moreover, my study focuses on a reform of the NRA (rather than ERA); since the reform occurred relatively later in individuals' work lives (at 60-65 years old), this older affected population had lower time to adjust and faced greater difficulties in reentering the labor market in the case of job loss. Given this context, it is reasonable to expect larger responses in terms of pension claims and inactivity. Notice also that entering inactivity leaves workers without any income or subsidy so that employment-inactivity transitions arguably represent an involuntary and unforeseen outcome for older workers, which might be the result of firms' behavioral reactions (Bovini and Paradisi, 2019).

Other interesting comparisons regard the spillover effects on other welfare programs. Staubli and Zweimuller (2013), Geyer and Welteke (2019), and Rabaté and Rochut (2020) document considerable unintended consequences of raising the ERA on unemployment benefit, which increased by $12.5,5.2$, and 13.4 percentage points, respectively. Instead, according to my results, the largest program substitutions occurred through the disability channel, as in the case of the UK (Cribb et al., 2016) and the US (Duggan et al., 2007). This pattern of results is obviously influenced by the options available to workers in their own country. For example, the low response registered along the disability exit route in Austria likely depends on the fact that most poor health workers leave the labor market already before the age of 60 through an alternative disability program (Staubli, 2011). The unemployment benefit response was much more limited in Italy with respect to France, Germany, and Austria, i.e., countries where the risk of unemployment has traditionally been more effectively met by the welfare system, with benefits that are granted for longer and with higher replacement rates, resulting in a stronger incentive on the worker's side. In Italy, it is reasonable to expect that more recent reforms could be accompanied by more pronounced unemployment effects, given the increased availability and generosity of unemployment benefits schemes.

The heterogeneity analysis presented in this study revealed that the NRA raise affected certain groups differently, hitting the disadvantaged categories harder. Very limited impact of the reform emerged for those employed as executives, in the highest wage tertile, and with better health. In contrast, individuals employed as blue-collar, with poor health and low pay, proved fully constrained by the new pension rules. It is among them that I find the largest drop in pension claiming and the biggest increase in both employment rates and inactivity rates.

These results are in line with previous empirical studies showing that the effect on employment of a rise of the NRA is larger on low-educated workers treated by the reform in Switzerland (Hanel and Riphahn, 2012), in the USA (Mastrobuoni, 2009), and in Estonia (Soosaar et al., 2021). This pattern is also consistent with predictions from standard life cycle models, which show that limited financial possibilities, constituting a credit constraint, imposes stronger bounds on more disadvantaged workers, for whom to postpone claiming 
without extending working life would not be affordable. The results of this paper add to previous knowledge showing that occupation, wage, and health are all important factors that independently influence the direction and the size of the behavioral response to changed NRA, not only on employment but also on pension claims and, more worryingly, on inactivity.

The fact that workers in low skilled and low paid jobs are those who extend their working life the most despite their poorer health and despite being exposed to more physically demanding jobs, raises worries for the possible risks for their health (e.g., Carrino et al., 2020; Ardito et al., 2020; Ardito and Fleischmann, 2021) and quality of life (Di Gessa et al., 2018). Moreover, the increased inactivity rate is entirely borne by workers in low-paid and low-skilled jobs, for whom such increase exceeds the employment response. This result is novel to the literature and deserves further investigation. Since inactivity means living without any income from work, benefits, and without accumulating contributions, it should be ascertained what the main determinants of this undesired outcome are, whether demand or supply driven. Special attention should be given to protect older workers from the undesired consequences in terms of unequal pension wealth distribution and increased inequality (Morris, 2020) derived from involuntary withdrawals from the labor market.

\section{Conclusions}

This paper studies the short-run labor market effects of the 1992 Italian pension reform, which increased the NRA gradually from 60 to 65 for private-sector male employees.

The analysis is based on longitudinal social security data, and it adopts a DD method that exploits the exogenous discontinuities in pensionable age between cohorts. Results show that the reform succeeded in reducing pension claiming, although employment increased less than proportionally and inactivity and the demand for alternative welfare benefits also rose substantially.

I find that the impact of raising the NRA varies for workers with different socio-economic backgrounds. The more disadvantaged the worker, the stronger was the effect of the reform. Workers employed in manual jobs, with poorer health and lower wages showed the largest drop in pension claims and the highest employment growth. However, these workers were also more likely to become inactive, without any income from work or from social security.

Since increasing NRA beyond the age of 65 is becoming standard in most European countries, policymakers should be aware that these interventions hit the most vulnerable hardest, who consequently need to receive support to adapt to the challenges posed by pension reforms and to successfully extend working life.

\section{Conflict of Interest}

The author declares no conflict of interests for this article.

\section{Acknowledgments}

I am very grateful for the thoughtful comments of Roberto Leombruni, Lia Pacelli, Bernardo Fanfani, David Blane, Amanda Sacker, Nicholas Owen, Chiara Pronzato, Fabio Berton, Matteo Migheli, Enrico Rettore, Massimiliano Bratti, Traute Mayer. Part of the research was carried out while I was visiting the ICLS at University College London, I thank them for their hospitality. Thanks to the LABORatorio R. Revelli for providing access and support to the WHIP database. The financial support received from the International Association for 
Applied Econometrics is gratefully acknowledged (IAAE 2019 Student Travel Grant). A previous version of this paper circulated under the title "Rising pension age in Italy: employment response and program substitution". For information regarding the data utilized for this study and/or computer programs and/or additional results, please address correspondence to chiara.ardito@unito.it

\section{References}

Abdi, H. (2007): Bonferroni and Šidák Corrections for Multiple Comparisons. Encyclopedia of Measurement and Statistics 3, 103-107.

Ardito, C.; M. Fleischmann (2021): Health, Working Conditions and Retirement, in: Burnay, N., Krekula, C., Ogg, J., Vendramin, P. (eds.) Older Workers and Exclusion Processes on the Labour Market: A Life Course Perspective, Springer: Life Course Research and Social Policies Collection, Forthcoming.

Ardito, C.; R. Leombruni; D. Blane; A. d'Errico (2020): To Work or Not to Work? The Effect of Higher Pension Age on Cardiovascular Health. Industrial Relations: A Journal of Economy and Society 59(3), 353-499.

Arpaia, A..; K. Dybczak; F. Pierini (2009): Assessing the Short-term Impact of Pension Reforms on Older Workers' Participation Rates in the EU: A Diff-in-Diff Approach, Economic Paper, 385. Directorate General Economic and Financial Affairs, European Commission, Brussels.

Atalay, K.; G. F. Barrett (2015): The Impact of Age Pension Eligibility Age on Retirement and Program Dependence: Evidence from an Australian Experiment. Review of Economics and Statistics 97(1), 71-87.

Attanasio, O. P.; A. Brugiavini (2003): Social Security and Households' Savings. Quarterly Journal of Economics 118(3), 1075-1119.

Autor, D. H. (2003): Outsourcing at Will: Unjust Dismissal Doctrine and the Growth of Temporary Help Employment. Journal of Labor Economics 21(1), 1-42.

Autor, D. H.; M. G. Duggan (2003): The Rise in the Disability Rolls and the Decline in Unemployment. The Quarterly Journal of Economics 118(1), 157-205.

Baker, A.; D. F. Larcker; C. C. Wang (2021): How Much Should We Trust Staggered Difference-In-Differences Estimates?. Available at SSRN 3794018.

Behaghel, L.; D. M. Blau (2012): Framing Social Security Reform: Behavioral Responses to Changes in the Full Retirement Age. American Economic Journal: Economic Policy 4(4), 41-67.

Bena, A.; M. Giraudo; R. Leombruni; G. Costa (2012): A New Italian Surveillance System for Occupational Injuries: Characteristics and Initial Results. American Journal of Industrial Medicine 55(7), 584-592.

Blundell, R.; E. French; G. Tetlow (2016): Retirement Incentives and Labor Supply, in: Piggott, John \& Woodland, Alan (eds.), Handbook of the Economics of Population Aging, Vol. 1. Elsevier, 457-566.

Borghans, L.; A. C. Gielen; E. F. Luttmer (2014): Social Support Substitution and the Earnings Rebound: Evidence From a Regression Discontinuity in Disability Insurance Reform. American Economic Journal: Economic Policy 6(4), 34-70.

Börsch-Supan, A. H. (2015): Challenges for European Welfare States. International Tax and Public Finance 22(4), 534-548.

Bovini, G.; M. Paradisi (2019): Labor Substitutability and the Impact of Raising the Retirement Age. WorkINPS Papers No. 20.

Brinch, C. N.; O. L. Vestad; J. Zweimüller (2015): Excess Early Retirement? Evidence from the Norwegian 2011 Pension Reform. Mimeograph.

Brugiavini, A.; F. Peracchi (2012): Health Status, Welfare Programs Participation, and Labour Force Activity in Italy, in: David, W. (eds.) Social Security Programs and Retirement Around the World: Historical Trends in Mortality and Health, Employment, and Disability Insurance Participation and Reforms, Chiacgo: University of Chicago Press, 175-216.

Brugiavini, A. (1999): Social Security and Retirement in Italy, in: Gruber, J.; D. A. Wise (eds.) Social Security and Retirement Around the World, Chicago: University of Chicago Press, 1-35.

Brugiavini, A.; R. Buia; G. Pasini; G. Weber (2021): 6. The Evolution of Incentives for Retirement in Italy, 19802015, in: Social Security Programs and Retirement around the World, Chicago: University of Chicago Press, 227-270

Burtless, G.; R. Moffitt (1984): The Effect of Social Security Benefits on the Labor Supply of the Aged, in: Aaron, H. J.; G. Burtless (eds.) Washington, D.C: Retirement and Economic Behavior, Brookings Institution, 135-171.

Cameron, A. C.; J. B. Gelbach; D. L. Miller (2008): Bootstrap-Based Improvements for Inference with Clustered Errors. The Review of Economics and Statistics 90(3), 414-427.

Carrino, L.; K. Glaser; M. Avendano (2020): Later Retirement, Job Strain, and Health: Evidence from the New State Pension age in the United Kingdom. Health Economics 29(8), 891-912. 
Contini, B. (2002): Labour Mobility and Wage Dynamics in Italy (ed. by), Torino: Rosenberg \& Sellier Publishing.

Cribb, J.; C. Emmerson; G. Tetlow (2016): Signals Matter? Large Retirement Responses to Limited Financial Incentives. Labour Economics 42, 203-212.

De Chaisemartin, C.; X. D’Haultfœuille (2020b): Difference-in-Differences Estimators of Intertemporal Treatment Effects. Available at SSRN 3731856.

De Chaisemartin, C.; X. D’Haultfoeuille (2020a): Two-Way Fixed Effects Estimators with Heterogeneous Treatment Effects. American Economic Review 110(9), 2964-2996.

Di Gessa, G.; L. Corna; D. Price; K. Glaser (2018): The Decision to Work After State Pension Age and How it Affects Quality of Life: Evidence from a 6-year English Panel Study. Age and Ageing 47(3), 450-457.

Duggan, M.; P. Singleton; J. Song (2007): Aching to Retire? The Rise in the Full Retirement Age and Its Impact on the Social Security Disability Rolls. Journal of Public Economics 91(7), 1327-1350.

European Commission (2009): Joint Report on Social Protection and Social Inclusion 2009. Luxembourg: Office for Official Publications of the European Communities.

Evers, M.; R. De Mooij; D. Van Vuuren (2008): The Wage Elasticity of Labour Supply: A Synthesis of Empirical Estimates. De Economist 156(1), 25-43.

Geyer, J.; C. Welteke (2019): Closing Routes to Retirement for Women: How Do They Respond? Journal of Human Resources 56(1), 311-341.

Gruber, J.; D. A. Wise (eds.) 2007: Social Security Programs and Retirement Around the World: Fiscal Implications of Reform, Chicago: University of Chicago Press.

Gruber, J.; D. A. Wise (1999): Social Security and Retirement Around the World, Chicago: University of Chicago Press.

Gustman, A. L.; T. L. Steinmeier (1985): The 1983 Social Security Reforms and Labor Supply Adjustments of Older Individuals in the Long Run. Journal of Labor Economics 3(2), 237-253.

Hall, B. H.; J. Mairesse; L. Turner (2007): Identifying Age, Cohort, and Period Effects in Scientific Research Productivity: Discussion and Illustration Using Simulated and Actual Data on French Physicists. Economics of Innovation and New Technology 16(2), 159-177.

Hanel, B.; R. T. Riphahn (2012): The Timing of Retirement-New Evidence from Swiss Female Workers. Labour Economics 19(5), 718-728.

Inderbitzin, L.; S. Staubli; J. Zweimüller (2016): Extended Unemployment Benefits and Early Retirement: Program Complementarity and Program Substitution. American Economic Journal: Economic Policy 8(1), 253-288.

ISTAT (2011): Statistiche Della Previdenza e Dell'Assistenza Sociale. I-I Trattamenti Pensionistici - Anno 2008. Roma: Collana Annuari, 15.

Krueger, A. B.; J. S. Pischke (1992): The Effect of Social Security on Labor Supply: A Cohort Analysis of the Notch Generation. Journal of Labor Economics 10(4), 412-437.

Leombruni R.; M. Mosca (2014): The Redistributive Features of Italian Pension System: The Importance of Being Neutral, in: Dekkers, G.; M. E. Keegan; C. O’Donoghue, New Pathways in Microsimulation, Farnham, Surrey: Ashgate, 126.

Leombruni, R.; M. Mosca (2012): Le Système de Retraite Italien Compense-t-il les Inégalités Hommes-Femmes sur le marché du travail ?, Retraite et Société 2(63), 139-163.

Leombruni, R.; A. Paggiaro; U. Trivellato (2012): Per un Pugno di euro. Storie di ordinaria disoccupazione. Politica Economica 28(1), 5-48.

Manoli, D. S.; A. Weber (2016): The Effects of the Early Retirement Age on Retirement Decisions. National Bureau of Economic Research w22561.

Mastrobuoni, G. (2009): Labor Supply Effects of the Recent Social Security Benefit Cuts: Empirical Estimates Using Cohort Discontinuities. Journal of Public Economics 93(11), 1224-1233.

Melis, A.; B. Lüdeke (2006): Registered Unemployment (RU) Compared with Harmonised Unemployed (LFS) Working Papers and Studies. Luxembourg: Office for Official Publications of the European Communities.

MISSOC. (2021): Mutual Information System on Social Protection database. Selected update: 2016-01-01. Selected topics: V. and VI. Available at: https://www.missoc.org/missoc-database/comparative-tables/ (Accessed on 01 September 1, 2021).

Natali, D.; S. Spasova; B. Vanhercke (2016): Retirement Regimes for Workers in Arduous or Hazardous Jobs. A Study of National Policies, European Social Policy Network (ESPN), Brussels: European Commission. Available online at: https://op.europa.eu/it/publication-detail/-/publication/e23e8180-9ac9-11e6-868c01aa75ed71a1 Accessed on 5 July 2021.

OECD (2019): OECD Pensions at a Glance 2019: OECD and G20 Indicators, Paris: OECD Publishing. doi:10.1787/ b6d3dcfc-en. 
Oguzoglu, U.; C. Polidano; H. Vu (2020): Impacts from Delaying Access to Retirement Benefits on Welfare Receipt and Expenditure: Evidence from a Natural Experiment. Economic Record 96(312), 65-86.

Rabaté, S.; J. Rochut (2020): Employment and Substitution Effects of Raising the Statutory Retirement Age in France. Journal of Pension Economics \& Finance 19(3), 293-308.

Soosaar, O; A. Puur; L. Leppik (2021): Does Raising the Pension Age Prolong Working Life? Evidence from Pension Age Reform in Estonia. Journal of Pension Economics \& Finance 20(2), 317-335.

Staubli, S. (2011): The Impact of Stricter Criteria for Disability Insurance on Labor Force Participation. Journal of Public Economics 95(9), 1223-1235.

Staubli, S.; J. Zweimüller (2013): Does Raising the Early Retirement Age Increase Employment of Older Workers?. Journal of Public Economics 108, 17-32. 


\section{Online Supplementary Materials}

\section{Appendix A}

\section{Unemployment benefit schemes}

In the years of the reform under scrutiny, there were three broad categories of unemployment schemes: an ordinary unemployment benefit, a short-time work scheme, and a long-term unemployment benefit.

In order to be eligible for the "ordinary unemployment benefit" (indennità di disoccupazione ordinaria) ${ }^{19}$, workers who have lost their job, quit for just cause, or whose contract was terminated must have paid contributions to the Social Security for at least 2 years accumulating at least 52 weeks of contributions before their dismissal ${ }^{20}$. Furthermore, the worker must be registered at a public employment service and be immediately available for work. The amount of benefit is calculated as a percentage of the gross income earned by workers over their two previous years of work and the replacement rate was increased over the years, starting from a very low $7.5 \%$ in 1988 to $60 \%$ in 2008 . Also, the duration of the benefit was gradually extended over the years, from 6 months in 1999 up to 12 months for workers aged fifty and older, in 2012. The very low replacement rate and short duration during the years under analysis (1986-2001) considerably limited the application of this benefit, which started becoming economically attractive only from 2005 (Leombruni et al., 2012).

"Short time work" (cassa integrazione guadagni, CIG) is an income supporting scheme available only to workers employed in industry or construction firms with fifteen or more employees, which go through temporary reduction or cease activity due to cyclical weakness or unforeseen events. Although workers under this scheme maintain their contractual attachment formally, work activity is interrupted and they receive a generous benefit replacing around $80 \%$ of their average earnings subject to a monthly ceiling, up to maximum 12 months. Extension by up to 3 years is available for workers employed in firms facing crisis and/or restructuring (cassa integrazione guadagni straordinaria, CIG-S).

The "long-term unemployment benefit" (Indennità di mobilità), is already available to dismissed workers in CIG-S and/or to firms eligible for benefits from CIG. It was introduced in 1991 to facilitate the drastic economic restructuring that occurred in the late 1980s in the Italian economy and was often used as a path to retirement. The benefit duration varies from 12 months to 48 months, depending on the worker's age (shorter for younger) and area of residence (shorter for northern regions). The benefit is quite generous as it amounts to $80 \%$ of average earnings (subject to a ceiling) during the first 12 months and then drops to $60 \%$ for the subsequent months.

19 The benefit has been replaced by the ASpI (Assicurazione Sociale per l'Impiego) since 2013, which in turn have been replaced by the NASPI (Nuova prestazione di Assicurazione Sociale per l'Impiego) and ASDI (Assegno di DIsoccupazione) in May 2015 (Anastasia et al. 2015).

20 A reduced (ordinary) unemployment benefit can be also claimed by those who do not qualify for ordinary unemployment benefit but worked at least 78 days in the year leading up to their dismissal. The benefit has been replaced by the MiniASpI since 2013 . 


\section{Appendix B}

Table B1 Calendar years and ages for the treated and untreated cohorts

\begin{tabular}{|c|c|c|c|c|c|c|c|c|c|c|c|c|c|}
\hline & \multicolumn{12}{|c|}{ Year-Semester Birth Cohorts } \\
\hline & & 1931-1 & $1931-2$ & $1932-1$ & $1932-2$ & $1933-1$ & $1933-2$ & 1934-1 & 1934-2 & $1935-1$ & $1935-2$ & 1936-1 & $1936-2$ \\
\hline \multicolumn{14}{|c|}{ NRA by Period } \\
\hline 60 & 1986-1 & 55 & - & - & - & - & - & - & - & - & - & - & - \\
\hline 60 & $1986-2$ & 55 & 55 & - & - & - & - & - & - & - & - & - & - \\
\hline 60 & 1987-1 & 56 & 55 & 55 & - & - & - & - & - & - & - & - & - \\
\hline 60 & $1987-2$ & 56 & 56 & 55 & 55 & - & - & - & - & - & - & - & - \\
\hline 60 & 1988-1 & 57 & 56 & 56 & 55 & 55 & - & - & - & - & - & - & - \\
\hline 60 & $1988-2$ & 57 & 57 & 56 & 56 & 55 & 55 & - & - & - & - & - & - \\
\hline 60 & 1989-1 & 58 & 57 & 57 & 56 & 56 & 55 & 55 & - & - & - & - & - \\
\hline 60 & 1989-2 & 58 & 58 & 57 & 57 & 56 & 56 & 55 & 55 & - & - & - & - \\
\hline 60 & 1990-1 & 59 & 58 & 58 & 57 & 57 & 56 & 56 & 55 & 55 & - & - & - \\
\hline 60 & 1990-2 & 59 & 59 & 58 & 58 & 57 & 57 & 56 & 56 & 55 & 55 & - & - \\
\hline 60 & 1991-1 & 60 & 59 & 59 & 58 & 58 & 57 & 57 & 56 & 56 & 55 & 55 & - \\
\hline 60 & $1991-2$ & 60 & 60 & 59 & 59 & 58 & 58 & 57 & 57 & 56 & 56 & 55 & 55 \\
\hline 60 & 1992-1 & 61 & 60 & 60 & 59 & 59 & 58 & 58 & 57 & 57 & 56 & 56 & 55 \\
\hline 60 & $1992-2$ & 61 & 61 & 60 & 60 & 59 & 59 & 58 & 58 & 57 & 57 & 56 & 56 \\
\hline 60 & 1993-1 & 62 & 61 & 61 & 60 & 60 & 59 & 59 & 58 & 58 & 57 & 57 & 56 \\
\hline 60 & 1993-2 & 62 & 62 & 61 & 61 & 60 & 60 & 59 & 59 & 58 & 58 & 57 & 57 \\
\hline 61 & 1994-1 & 63 & 62 & 62 & 61 & 61 & 60 & 60 & 59 & 59 & 58 & 58 & 57 \\
\hline 61 & 1994-2 & 63 & 63 & 62 & 62 & 61 & 61 & 60 & 60 & 59 & 59 & 58 & 58 \\
\hline 61 & 1995-1 & 64 & 63 & 63 & 62 & 62 & 61 & 61 & 60 & 60 & 59 & 59 & 58 \\
\hline 62 & $1995-2$ & 64 & 64 & 63 & 63 & 62 & 62 & 61 & 61 & 60 & 60 & 59 & 59 \\
\hline 62 & 1996-1 & 65 & 64 & 64 & 63 & 63 & 62 & 62 & 61 & 61 & 60 & 60 & 59 \\
\hline 62 & $1996-2$ & 65 & 65 & 64 & 64 & 63 & 63 & 62 & 62 & 61 & 61 & 60 & 60 \\
\hline 63 & 1997-1 & - & 65 & 65 & 64 & 64 & 63 & 63 & 62 & 62 & 61 & 61 & $\overline{60}$ \\
\hline 63 & $1997-2$ & - & - & 65 & 65 & 64 & 64 & 63 & 63 & 62 & 62 & 61 & 61 \\
\hline 63 & 1998-1 & - & - & - & 65 & 65 & 64 & 64 & 63 & 63 & 62 & 62 & 61 \\
\hline 64 & 1998-2 & - & - & - & - & 65 & 65 & 64 & 64 & 63 & 63 & 62 & 62 \\
\hline 64 & 1999-1 & - & - & - & - & - & 65 & 65 & 64 & 64 & 63 & 63 & 62 \\
\hline 64 & 1999-2 & - & - & - & - & - & - & 65 & 65 & 64 & 64 & 63 & 63 \\
\hline 65 & 2000-1 & - & - & - & - & - & - & - & 65 & 65 & 64 & 64 & 63 \\
\hline 65 & $2000-2$ & - & - & - & - & - & - & - & - & 65 & 65 & 64 & 64 \\
\hline 65 & 2001-1 & - & - & - & - & - & - & - & - & - & 65 & 65 & 64 \\
\hline 65 & 2001-2 & - & - & - & - & - & - & - & - & - & - & 65 & 65 \\
\hline 65 & $2002-1$ & - & - & - & - & - & - & - & - & - & - & - & 65 \\
\hline
\end{tabular}

Note: Each column lists the age of a given cohort in a particular semester. Each cell identifies the treatment and control groups in a particular age and period. Cells identify treatment if Age $<$ NRA (grey color) and control if Age $>=$ NRA (white). The composition of treated and control groups evolves with the gradual increase of NRA as shown in Table 3. For example, individuals born in the first half of 1934 (i.e., 1934-I) are "treated" only in their 60th year of age and contribute to the estimation of the effect of a rise of NRA from 60 to 61 as part of the treated group, but in the following step-wise increases (from 61 to 65) they will act as a control, as long as they had already reached NRA in 1995-I. The average DD treatment effect is identified only for the ages 60-64 (area included in the red rhombus) for which there is within and between cohort variation.

DD, difference-in-differences; NRA, normal retirement age. 


\section{Appendix C}

Table C1 Effect of rising the NRA on different labor market outcomes at every single age (before, during, and after the NRA rise) Eq. (1)

\begin{tabular}{|c|c|c|c|c|c|}
\hline & $\begin{array}{l}\text { Pension } \\
\text { benefit }\end{array}$ & Employment & Inactivity & $\begin{array}{c}\text { Disability } \\
\text { benefit }\end{array}$ & $\begin{array}{c}\text { Unemployment } \\
\text { benefit }\end{array}$ \\
\hline \multicolumn{6}{|c|}{ Interaction of Treated group (T) and Age dummies (Ref. Category: T X Age55) } \\
\hline T $\times$ Age56 & 0.01 & -0.004 & -0.032 & -0.012 & -0.002 \\
\hline WB Šidàk $p$ & $(0.5612)$ & $(1.000)$ & $(0.183)$ & $(0.000)$ & (0.999) \\
\hline T $\times$ Age57 & 0.016 & -0.008 & -0.033 & -0.013 & -0.005 \\
\hline WB Šidàk $p$ & $(0.2853)$ & $(0.982)$ & $(0.479)$ & $(0.03)$ & $(1.000)$ \\
\hline T $\times$ Age58 & 0.019 & -0.008 & -0.029 & -0.013 & 0.007 \\
\hline WB Šidàk $p$ & $(0.5753)$ & $(1.000)$ & $(0.943)$ & $(0.039)$ & $(0.628)$ \\
\hline T×Age59 & 0.022 & -0.008 & -0.034 & -0.009 & 0.008 \\
\hline WB Šidàk $p$ & $(0.4141)$ & (0.999) & $(0.854)$ & $(0.432)$ & $(0.462)$ \\
\hline $\mathrm{T} \times$ Age60 & $-0.546^{\star \star \star}$ & $0.076^{\star \star}$ & 0.073 & 0.011 & 0.015 \\
\hline WB Šidàk $p$ & $(0.000)$ & $(0.01)$ & $(0.712)$ & $(0.571)$ & $(0.948)$ \\
\hline T $\times$ Age 61 & $-0.568^{\star \star}$ & $0.16^{\star \star}$ & $0.221^{\star \star}$ & $0.045^{\star \star \star}$ & $0.03^{\star \star \star}$ \\
\hline WB Šidàk $p$ & $(0.01)$ & $(0.01)$ & $(0.03)$ & $(0.000)$ & $(0.000)$ \\
\hline T $\times$ Age 62 & $-0.546^{\star \star \star}$ & $0.136^{\star \star \star}$ & $0.236^{\star \star}$ & $0.061^{\star \star \star}$ & $0.029^{\star \star}$ \\
\hline WB Šidàkp & $(0.000)$ & $(0.000)$ & $(0.01)$ & $(0.000)$ & $(0.01)$ \\
\hline T $\times$ Age 63 & $-0.517^{\star \star}$ & $0.112^{\star \star}$ & $0.235^{\star \star}$ & $0.071^{\star \star}$ & $0.023^{\star \star}$ \\
\hline WB Šidàkp & $(0.01)$ & $(0.02)$ & $(0.02)$ & $(0.02)$ & $(0.039)$ \\
\hline T×Age64 & $-0.503^{\star \star \star}$ & $0.092^{\star \star \star}$ & $0.22^{*}$ & 0.061 & 0.019 \\
\hline WB Šidàk $p$ & $(0.000)$ & $(0.000)$ & $(0.059)$ & $(0.27)$ & $(0.278)$ \\
\hline \multirow[t]{2}{*}{ T×Age65 } & 0.014 & -0.007 & -0.014 & -0.007 & -0.005 \\
\hline & (0.9999) & $(1.000)$ & $(1.000)$ & (0.999) & $(0.964)$ \\
\hline \multicolumn{6}{|c|}{ Year-semester of birth dummies (Ref. Category: 1931 - I sem) } \\
\hline 1931 - II sem & $-0.019^{\star \star}$ & $0.040^{\star \star \star}$ & 0.022 & $0.007^{\star \star \star}$ & $0.005^{\star \star}$ \\
\hline 1932 - I sem & $-0.048^{\star \star \star}$ & $0.070^{\star \star \star}$ & $0.070^{\star \star \star}$ & $0.014^{\star \star \star}$ & $0.015^{\star \star \star}$ \\
\hline 1932 - II sem & $-0.070^{\star \star \star}$ & $0.099^{\star \star \star}$ & $0.101^{\star \star \star}$ & $0.010^{\star \star}$ & $0.022^{\star \star \star}$ \\
\hline 1933 - I sem & $-0.123^{\star \star \star}$ & $0.137^{\star \star \star}$ & $0.144^{\star \star \star}$ & $0.023^{\star \star \star}$ & $0.028^{\star \star \star}$ \\
\hline 1933 - II sem & $-0.136^{\star \star \star}$ & $0.167^{\star \star \star}$ & $0.171^{\star \star \star}$ & $0.025^{\star \star \star}$ & $0.035^{\star \star \star}$ \\
\hline 1934 - I sem & $-0.193^{\star \star \star}$ & $0.228^{\star \star \star}$ & $0.245^{\star \star \star}$ & $0.050^{\star \star \star}$ & $0.054^{\star \star \star}$ \\
\hline 1934 - II sem & $-0.220^{\star \star \star}$ & $0.275^{\star \star \star}$ & $0.277^{\star \star \star}$ & $0.051^{\star \star \star}$ & $0.066^{\star \star \star}$ \\
\hline 1935 - I sem & $-0.257^{\star \star \star}$ & $0.308^{\star \star \star}$ & $0.319^{\star \star \star}$ & $0.067^{\star \star \star}$ & $0.072^{\star \star \star}$ \\
\hline 1935 - II sem & $-0.268^{\star \star \star}$ & $0.338^{\star \star \star}$ & $0.353^{\star \star \star}$ & $0.062^{\star \star \star}$ & $0.075^{\star \star \star}$ \\
\hline 1936 - I sem & $-0.278^{\star \star \star}$ & $0.358^{\star \star \star}$ & $0.388^{\star \star \star}$ & $0.066^{\star \star \star}$ & $0.080^{\star \star \star}$ \\
\hline 1936 - II sem & $-0.287^{\star \star \star}$ & $0.383^{\star \star \star}$ & $0.420^{\star \star \star}$ & $0.059^{\star \star \star}$ & $0.092^{\star \star \star}$ \\
\hline \multicolumn{6}{|c|}{ Year-semester dummies (Ref. Category: 1986 - I sem) } \\
\hline 1986 - II sem & $0.021^{\star \star \star}$ & $-0.029^{\star \star \star}$ & $-0.025^{\star \star \star}$ & $0.003^{\star \star}$ & 0 \\
\hline 1987 - I sem & $0.057^{\star \star \star}$ & $-0.101^{\star \star \star}$ & $-0.060^{\star \star \star}$ & -0.002 & 0 \\
\hline 1987 - II sem & $0.075^{\star \star \star}$ & $-0.119^{\star \star \star}$ & $-0.098^{\star \star \star}$ & -0.002 & -0.005 \\
\hline 1988 - I sem & $0.112^{\star \star \star}$ & $-0.168^{\star \star \star}$ & $-0.138^{\star \star \star}$ & -0.004 & $-0.017^{\star \star \star}$ \\
\hline 1988 - II sem & $0.134^{\star \star \star}$ & $-0.191^{\star \star \star}$ & $-0.183^{\star \star \star}$ & -0.005 & $-0.022^{\star \star \star}$ \\
\hline 1989 - I sem & $0.172^{\star \star \star}$ & $-0.246^{\star \star \star}$ & $-0.224^{\star \star \star}$ & -0.009 & $0.023^{\star \star \star}$ \\
\hline 1989 - II sem & $0.192^{\star \star \star}$ & $-0.269^{\star \star \star}$ & $-0.268^{\star \star \star}$ & -0.012 & $0.018^{\star \star}$ \\
\hline
\end{tabular}


Table C1 Continued

\begin{tabular}{|c|c|c|c|c|c|}
\hline & $\begin{array}{l}\text { Pension } \\
\text { benefit }\end{array}$ & Employment & Inactivity & $\begin{array}{c}\text { Disability } \\
\text { benefit }\end{array}$ & $\begin{array}{c}\text { Unemployment } \\
\text { benefit }\end{array}$ \\
\hline 1990 - I sem & $0.216^{\star \star \star}$ & $-0.306^{\star \star \star}$ & $-0.302^{\star \star \star}$ & -0.014 & $0.038^{\star \star \star}$ \\
\hline 1990 - II sem & $0.236^{\star \star \star}$ & $-0.332^{\star \star \star}$ & $-0.342^{\star \star \star}$ & -0.017 & $0.034^{\star \star \star}$ \\
\hline 1991 - I sem & $0.254^{\star \star \star}$ & $-0.365^{\star \star \star}$ & $-0.354^{\star \star \star}$ & -0.018 & $0.046^{\star \star \star}$ \\
\hline 1991 - II sem & $0.277^{\star \star \star}$ & $-0.397^{\star \star \star}$ & $-0.410^{\star \star \star}$ & -0.022 & $0.045^{\star \star \star}$ \\
\hline 1992 - I sem & $0.303^{\star \star \star}$ & $-0.443^{\star \star \star}$ & $-0.436^{\star \star \star}$ & -0.023 & $0.029^{\star \star}$ \\
\hline 1992 - II sem & $0.327^{\star \star \star}$ & $-0.476^{\star \star \star}$ & $-0.474^{\star \star \star}$ & -0.028 & $0.034^{\star \star}$ \\
\hline 1993 - I sem & $0.340^{\star \star \star}$ & $-0.537^{\star \star \star}$ & $-0.495^{\star \star \star}$ & -0.03 & 0.025 \\
\hline 1993 - II sem & $0.353^{\star \star \star}$ & $-0.573^{\star \star \star}$ & $-0.531^{\star \star \star}$ & -0.034 & 0.033 \\
\hline 1994 - I sem & $0.385^{\star \star \star}$ & $-0.637^{\star \star \star}$ & $-0.576^{\star \star \star}$ & -0.039 & 0.01 \\
\hline 1994 - II sem & $0.403^{\star \star \star}$ & $-0.660^{\star \star \star}$ & $-0.593^{\star \star \star}$ & -0.041 & 0.011 \\
\hline 1995 - I sem & $0.421^{\star \star \star}$ & $-0.690^{\star \star \star}$ & $-0.602^{\star \star \star}$ & -0.041 & 0 \\
\hline 1995 - II sem & $0.439^{\star \star \star}$ & $-0.723^{\star \star \star}$ & $-0.658^{\star \star \star}$ & -0.045 & -0.006 \\
\hline 1996 - I sem & $0.461^{\star \star \star}$ & $-0.762^{\star \star \star}$ & $-0.685^{\star \star \star}$ & -0.049 & -0.013 \\
\hline 1996 - II sem & $0.480^{\star \star \star}$ & $-0.780^{\star \star \star}$ & $-0.693^{\star \star \star}$ & -0.047 & -0.017 \\
\hline 1997 - I sem & $0.514^{\star \star \star}$ & $-0.834^{\star \star \star}$ & $-0.750^{\star \star \star}$ & -0.053 & -0.035 \\
\hline 1997 - II sem & $0.535^{\star \star \star}$ & $-0.861^{\star \star \star}$ & $-0.781^{\star \star \star}$ & -0.056 & -0.039 \\
\hline 1998 - I sem & $0.551^{\star \star \star}$ & $-0.893^{\star \star \star}$ & $-0.777^{\star \star \star}$ & -0.05 & -0.048 \\
\hline 1998 - II sem & $0.581^{\star \star \star}$ & $-0.933^{\star \star \star}$ & $-0.848^{\star \star \star}$ & -0.058 & -0.054 \\
\hline 1999 - I sem & $0.608^{\star \star \star}$ & $-0.973^{\star \star \star}$ & $-0.873^{\star \star \star}$ & -0.06 & $-0.066^{\star \star}$ \\
\hline 1999 - II sem & $0.616^{\star \star \star}$ & $-0.990^{\star \star \star}$ & $-0.877^{\star \star \star}$ & -0.049 & $-0.070^{\star \star}$ \\
\hline 2000 - I sem & $0.652^{\star \star \star}$ & $-1.025^{\star \star \star}$ & $-0.947^{\star \star \star}$ & -0.05 & $-0.083^{\star \star}$ \\
\hline 2000 - II sem & $0.677^{\star \star \star}$ & $-1.050^{\star \star \star}$ & $-0.974^{\star \star \star}$ & -0.042 & $-0.088^{\star \star}$ \\
\hline 2001 - I sem & $0.679^{\star \star \star}$ & $-1.063^{\star \star \star}$ & $-0.908^{\star \star \star}$ & -0.008 & $-0.089^{\star \star}$ \\
\hline 2001 - II sem & $0.672^{\star \star \star}$ & $-1.075^{\star \star \star}$ & $-0.933^{\star \star \star}$ & 0.01 & $-0.087^{\star \star}$ \\
\hline 2002 - I sem & $0.742^{\star \star \star}$ & $-1.142^{\star \star \star}$ & $-1.109^{\star \star \star}$ & -0.017 & $-0.112^{\star \star \star}$ \\
\hline \multicolumn{6}{|c|}{ Age dummies (Reference Category: 55 years old) } \\
\hline 56 & $-0.038^{\star \star \star}$ & $0.045^{\star \star \star}$ & $0.080^{\star \star \star}$ & $0.020^{\star \star \star}$ & $0.013^{\star \star \star}$ \\
\hline 57 & $-0.079^{\star \star \star}$ & $0.091^{\star \star \star}$ & $0.156^{\star \star \star}$ & $0.037^{\star \star \star}$ & $0.025^{\star \star \star}$ \\
\hline 58 & $-0.117^{\star \star \star}$ & $0.132^{\star \star \star}$ & $0.234^{\star \star \star}$ & $0.053^{\star \star \star}$ & $0.030^{\star \star \star}$ \\
\hline 59 & $-0.142^{\star \star \star}$ & $0.162^{\star \star \star}$ & $0.312^{\star \star \star}$ & $0.064^{\star \star \star}$ & $0.034^{\star \star \star}$ \\
\hline 60 & $0.483^{\star \star \star}$ & 0.07 & $0.276^{\star \star \star}$ & $0.059^{\star \star \star}$ & 0.006 \\
\hline 61 & $0.536^{\star \star \star}$ & -0.024 & $0.180^{\star \star}$ & 0.037 & $-0.030^{\star \star}$ \\
\hline 62 & $0.529^{\star \star \star}$ & 0.002 & $0.222^{\star \star}$ & 0.033 & -0.027 \\
\hline 63 & $0.506^{\star \star \star}$ & 0.043 & $0.274^{\star \star}$ & 0.033 & -0.016 \\
\hline 64 & $0.476^{\star \star \star}$ & 0.086 & $0.325^{\star \star \star}$ & 0.032 & -0.003 \\
\hline 65 & $0.503^{\star \star \star}$ & 0.122 & $0.366^{\star \star \star}$ & 0.038 & 0.011 \\
\hline _cons & $0.024^{\star \star \star}$ & $0.709^{\star \star \star}$ & $0.331^{\star \star \star}$ & $0.026^{\star \star \star}$ & $0.010^{\star \star \star}$ \\
\hline Adj. $R^{2}$ & 0.65 & 0.22 & 0.1 & 0.02 & 0.05 \\
\hline Observations & 659,428 & 659,428 & 659,428 & 659,428 & 659,428 \\
\hline
\end{tabular}

Notes: The table displays the regression output of Eq. (1) separately for each of the outcomes (columns). SE clustered at period level (33 groups) (sem=half year). Significance levels: ${ }^{* \star} 1 \%,{ }^{\star \star} 5 \%,{ }^{*} 10 \%$, based on: (a) WB procedure with 999 repetitions and Šidàk correction for five multiple hypotheses for the interactions terms TxAge, and (b) SE clustered for the remaining coefficients.

NRA, normal retirement age; WB, wild-cluster bootstrap. 
Table C2 The average effect of raising the NRA on different labor market outcomes Eq. (2)

\begin{tabular}{|c|c|c|c|c|c|}
\hline & $\begin{array}{l}\text { Pension } \\
\text { benefit }\end{array}$ & Employment & Inactivity & $\begin{array}{c}\text { Disability } \\
\text { Benefit }\end{array}$ & $\begin{array}{c}\text { Unemployment } \\
\text { benefit }\end{array}$ \\
\hline Age $<$ NRA & $-0.440^{\star \star \star}$ & $0.087^{\star \star \star}$ & $0.134^{\star \star \star}$ & $0.042^{\star \star \star}$ & $0.016^{\star \star \star}$ \\
\hline WB Šidàk p & $(0.000)$ & $(0.000)$ & $(0.000)$ & $(0.000)$ & $(0.206)$ \\
\hline \multicolumn{6}{|c|}{ Year-semester of birth dummies (Ref. Category: 1931 - I sem) } \\
\hline 1931 - II sem & $-0.035^{\star \star \star}$ & $0.043^{\star \star \star}$ & $0.027^{\star \star \star}$ & $0.009^{\star \star \star}$ & $0.006^{\star \star \star}$ \\
\hline 1932 - I sem & $-0.079^{\star \star \star}$ & $0.075^{\star \star \star}$ & $0.080^{\star \star \star}$ & $0.017^{\star \star \star}$ & $0.016^{\star \star \star}$ \\
\hline 1932 - II sem & $-0.115^{\star \star \star}$ & $0.107^{\star \star \star}$ & $0.116^{\star \star \star}$ & $0.015^{\star \star \star}$ & $0.023^{\star \star \star}$ \\
\hline 1933 - I sem & $-0.187^{\star \star \star}$ & $0.149^{\star \star \star}$ & $0.165^{\star \star \star}$ & $0.029^{\star \star \star}$ & $0.030^{\star \star \star}$ \\
\hline 1933 - II sem & $-0.194^{\star \star \star}$ & $0.177^{\star \star \star}$ & $0.189^{\star \star \star}$ & $0.031^{\star \star \star}$ & $0.037^{\star \star \star}$ \\
\hline 1934 - I sem & $-0.269^{\star \star \star}$ & $0.238^{\star \star \star}$ & $0.250^{\star \star \star}$ & $0.049^{\star \star \star}$ & $0.057^{\star \star \star}$ \\
\hline 1934 - II sem & $-0.327^{\star \star \star}$ & $0.296^{\star \star \star}$ & $0.295^{\star \star \star}$ & $0.052^{\star \star \star}$ & $0.071^{\star \star \star}$ \\
\hline 1935 - I sem & $-0.390^{\star \star \star}$ & $0.336^{\star \star \star}$ & $0.351^{\star \star \star}$ & $0.071^{\star \star \star}$ & $0.078^{\star \star \star}$ \\
\hline 1935 - II sem & $-0.425^{\star \star \star}$ & $0.372^{\star \star \star}$ & $0.398^{\star \star \star}$ & $0.070^{\star \star \star}$ & $0.084^{\star \star \star}$ \\
\hline 1936 - I sem & $-0.478^{\star \star \star}$ & $0.401^{\star \star \star}$ & $0.453^{\star \star \star}$ & $0.080^{\star \star \star}$ & $0.090^{\star \star \star}$ \\
\hline 1936 - II sem & $-0.505^{\star \star \star}$ & $0.428^{\star \star \star}$ & $0.490^{\star \star \star}$ & $0.075^{\star \star \star}$ & $0.103^{\star \star \star}$ \\
\hline \multicolumn{6}{|c|}{ Year-semester dummies (Ref. Category: 1986 - I sem) } \\
\hline 1986 - II sem & $0.029^{\star \star \star}$ & $-0.030^{\star \star \star}$ & $-0.028^{\star \star}$ & 0.002 & -0.001 \\
\hline 1987 - I sem & $0.083^{\star \star \star}$ & $-0.106^{\star \star \star}$ & $-0.066^{\star \star \star}$ & -0.003 & -0.001 \\
\hline 1987 - II sem & $0.113^{\star \star \star}$ & $-0.126^{\star \star \star}$ & $-0.106^{\star \star \star}$ & -0.004 & $-0.006^{\star \star}$ \\
\hline 1988 - I sem & $0.170^{\star \star \star}$ & $-0.179^{\star \star \star}$ & $-0.153^{\star \star \star}$ & -0.007 & $-0.019^{\star \star \star}$ \\
\hline 1988 - II sem & $0.202^{\star \star \star}$ & $-0.204^{\star \star \star}$ & $-0.201^{\star \star \star}$ & -0.009 & $-0.025^{\star \star \star}$ \\
\hline 1989 - I sem & $0.257^{\star \star \star}$ & $-0.262^{\star \star \star}$ & $-0.246^{\star \star \star}$ & -0.014 & $0.019^{\star \star \star}$ \\
\hline 1989 - II sem & $0.291^{\star \star \star}$ & $-0.288^{\star \star \star}$ & $-0.294^{\star \star \star}$ & $-0.017^{\star \star}$ & $0.013^{\star \star \star}$ \\
\hline 1990 - I sem & $0.338^{\star \star \star}$ & $-0.331^{\star \star \star}$ & $-0.343^{\star \star \star}$ & $-0.024^{\star \star}$ & $0.032^{\star \star \star}$ \\
\hline 1990 - II sem & $0.374^{\star \star \star}$ & $-0.360^{\star \star \star}$ & $-0.388^{\star \star \star}$ & $-0.029^{\star \star \star}$ & $0.027^{\star \star \star}$ \\
\hline 1991 - I sem & $0.421^{\star \star \star}$ & $-0.399^{\star \star \star}$ & $-0.411^{\star \star \star}$ & $-0.033^{\star \star}$ & $0.037^{\star \star \star}$ \\
\hline 1991 - II sem & $0.463^{\star \star \star}$ & $-0.435^{\star \star \star}$ & $-0.472^{\star \star \star}$ & $-0.037^{\star \star \star}$ & $0.036^{\star \star \star}$ \\
\hline 1992 - I sem & $0.513^{\star \star \star}$ & $-0.488^{\star \star \star}$ & $-0.513^{\star \star \star}$ & $-0.042^{\star \star \star}$ & $0.021^{\star \star}$ \\
\hline 1992 - II sem & $0.555^{\star \star \star}$ & $-0.526^{\star \star \star}$ & $-0.561^{\star \star \star}$ & $-0.050^{\star \star \star}$ & $0.024^{\star \star}$ \\
\hline 1993 - I sem & $0.589^{\star \star \star}$ & $-0.593^{\star \star \star}$ & $-0.593^{\star \star \star}$ & $-0.055^{\star \star \star}$ & 0.016 \\
\hline 1993 - II sem & $0.619^{\star \star \star}$ & $-0.633^{\star \star \star}$ & $-0.638^{\star \star \star}$ & $-0.062^{\star \star \star}$ & $0.023^{\star \star \star}$ \\
\hline 1994 - I sem & $0.691^{\star \star \star}$ & $-0.708^{\star \star \star}$ & $-0.703^{\star \star \star}$ & $-0.074^{\star \star \star}$ & -0.002 \\
\hline 1994 - II sem & $0.678^{\star \star \star}$ & $-0.727^{\star \star \star}$ & $-0.720^{\star \star \star}$ & $-0.077^{\star \star \star}$ & 0.001 \\
\hline 1995 - I sem & $0.709^{\star \star \star}$ & $-0.758^{\star \star \star}$ & $-0.730^{\star \star \star}$ & $-0.077^{\star \star \star}$ & -0.012 \\
\hline 1995 - II sem & $0.772^{\star \star \star}$ & $-0.796^{\star \star \star}$ & $-0.797^{\star \star \star}$ & $-0.086^{\star \star \star}$ & -0.019 \\
\hline 1996 - I sem & $0.756^{\star \star \star}$ & $-0.822^{\star \star \star}$ & $-0.801^{\star \star \star}$ & $-0.085^{\star \star \star}$ & $-0.024^{\star \star}$ \\
\hline 1996 - II sem & $0.789^{\star \star \star}$ & $-0.842^{\star \star \star}$ & $-0.812^{\star \star \star}$ & $-0.084^{\star \star \star}$ & $-0.028^{\star \star}$ \\
\hline 1997 - I sem & $0.870^{\star \star \star}$ & $-0.901^{\star \star \star}$ & $-0.872^{\star \star \star}$ & $-0.092^{\star \star \star}$ & $-0.047^{\star \star \star}$ \\
\hline 1997 - II sem & $0.864^{\star \star \star}$ & $-0.919^{\star \star \star}$ & $-0.885^{\star \star \star}$ & $-0.090^{\star \star \star}$ & $-0.049^{\star \star \star}$ \\
\hline 1998 - I sem & $0.904^{\star \star \star}$ & $-0.957^{\star \star \star}$ & $-0.888^{\star \star \star}$ & $-0.085^{\star \star \star}$ & $-0.059^{\star \star \star}$ \\
\hline 1998 - II sem & $1.007^{\star \star \star}$ & $-1.013^{\star \star \star}$ & $-0.974^{\star \star \star}$ & $-0.096^{\star \star \star}$ & $-0.067^{\star \star \star}$ \\
\hline 1999 - I sem & $0.992^{\star \star \star}$ & $-1.046^{\star \star \star}$ & $-0.979^{\star \star \star}$ & $-0.092^{\star \star \star}$ & $-0.080^{\star \star \star}$ \\
\hline 1999 - II sem & $1.028^{\star \star \star}$ & $-1.071^{\star \star \star}$ & $-0.994^{\star \star \star}$ & $-0.082^{\star \star \star}$ & $-0.086^{\star \star \star}$ \\
\hline
\end{tabular}


Table C2 Continued

\begin{tabular}{|c|c|c|c|c|c|}
\hline & $\begin{array}{l}\text { Pension } \\
\text { benefit }\end{array}$ & Employment & Inactivity & $\begin{array}{c}\text { Disability } \\
\text { Benefit }\end{array}$ & $\begin{array}{c}\text { Unemployment } \\
\text { benefit }\end{array}$ \\
\hline $2000-$ I sem & $1.171^{\star \star \star}$ & $-1.131^{\star \star \star}$ & $-1.093^{\star \star \star}$ & $-0.093^{\star \star \star}$ & $-0.104^{\star \star \star}$ \\
\hline $2000-$ II sem & $1.130^{\star \star \star}$ & $-1.146^{\star \star \star}$ & $-1.095^{\star \star \star}$ & $-0.079^{\star \star}$ & $-0.107^{\star \star \star}$ \\
\hline 2001 - I sem & $1.166^{\star \star \star}$ & $-1.166^{\star \star \star}$ & $-1.051^{\star \star \star}$ & -0.051 & $-0.110^{\star \star \star}$ \\
\hline 2001 - II sem & $1.212^{\star \star \star}$ & $-1.188^{\star \star \star}$ & $-1.113^{\star \star \star}$ & -0.043 & $-0.112^{\star \star \star}$ \\
\hline 2002 - I sem & $1.277^{\star \star \star}$ & $-1.249^{\star \star \star}$ & $-1.278^{\star \star \star}$ & $-0.064^{\star \star}$ & $-0.132^{\star \star \star}$ \\
\hline \multicolumn{6}{|c|}{ Age dummies (Reference Category: 55 years old) } \\
\hline 56 & $-0.069 * \star \star$ & $0.051^{\star \star \star}$ & $0.082^{\star \star \star}$ & $0.019^{\star \star \star}$ & $0.014^{\star \star \star}$ \\
\hline 57 & $-0.146^{\star \star \star}$ & $0.105^{\star \star \star}$ & $0.174^{\star \star \star}$ & $0.040^{\star \star \star}$ & $0.028^{\star \star \star}$ \\
\hline 58 & $-0.220^{\star \star \star}$ & $0.154^{\star \star \star}$ & $0.271^{\star \star \star}$ & $0.062^{\star \star \star}$ & $0.038^{\star \star \star}$ \\
\hline 59 & $-0.282^{\star \star \star}$ & $0.194^{\star \star \star}$ & $0.369^{\star \star \star}$ & $0.080^{\star \star \star}$ & $0.043^{\star \star \star}$ \\
\hline 60 & $-0.165^{\star \star}$ & $0.189^{\star \star \star}$ & $0.459^{\star \star \star}$ & $0.110^{\star \star \star}$ & $0.027^{\star \star \star}$ \\
\hline 61 & -0.134 & $0.130^{\star \star \star}$ & $0.430^{\star \star \star}$ & $0.106^{\star \star \star}$ & -0.003 \\
\hline 62 & -0.158 & $0.150^{\star \star \star}$ & $0.476^{\star \star \star}$ & $0.109^{\star \star \star}$ & -0.001 \\
\hline 63 & $-0.189^{\star \star}$ & $0.184^{\star \star \star}$ & $0.521^{\star \star \star}$ & $0.110^{\star \star \star}$ & 0.009 \\
\hline 64 & $-0.244^{\star \star}$ & $0.227^{\star \star \star}$ & $0.563^{\star \star \star}$ & $0.106^{\star \star \star}$ & 0.022 \\
\hline 65 & $-0.254^{\star \star}$ & $0.270^{\star \star \star}$ & $0.599^{\star \star \star}$ & $0.111^{\star \star \star}$ & $0.037^{\star \star}$ \\
\hline _cons & $0.464^{\star \star \star}$ & $0.622^{\star \star \star}$ & $0.197^{\star \star \star}$ & $-0.015^{\star \star \star}$ & -0.005 \\
\hline Adj. $R^{2}$ & 0.64 & 0.22 & 0.1 & 0.02 & 0.05 \\
\hline Observations & 659,428 & 659,428 & 659,428 & 659,428 & 659,428 \\
\hline
\end{tabular}

Notes: The table displays the regression output of Eq. (2) separately for each of the outcomes (columns). SE clustered at period level (33 groups) (sem=half year). Significance levels: ${ }^{\star \star \star} 1 \%,{ }^{\star \star} 5 \%,{ }^{\star} 10 \%$, based on: (a) WB procedure with 999 repetitions and Šidàk correction for five multiple hypotheses for the indicator terms Age $<N R A$, and (b) SE clustered for the remaining coefficients.

NRA, normal retirement age; WB, wild-cluster bootstrap. 
Table C3 Heterogeneous effect of rising the NRA: fully interacted analysis (based on Eq. (2))

\begin{tabular}{|c|c|c|c|c|c|}
\hline & $\begin{array}{l}\text { Pension } \\
\text { benefit }\end{array}$ & Employment & Inactivity & $\begin{array}{l}\text { Disability } \\
\text { benefit }\end{array}$ & $\begin{array}{c}\text { Unemployment } \\
\text { benefit }\end{array}$ \\
\hline Age $<$ NRA (Ref. Category ${ }^{a}$ ) & $-0.167^{\star \star \star}$ & 0.006 & -0.021 & $0.037^{\star \star \star}$ & $0.025^{\star \star \star}$ \\
\hline Age $<$ NRA $\times$ Low wage & $-0.092^{\star \star \star}$ & 0.004 & 0.056 & -0.011 & 0 \\
\hline$W P p$ & 0.000 & 0.871 & 0.031 & 0.081 & 0.955 \\
\hline WP p Šidàk correction & 0.000 & 1.000 & 0.451 & 0.288 & 1.000 \\
\hline Age $<$ NRA $\times$ Mid wage & $-0.052^{\star \star \star}$ & $0.022^{\star \star}$ & 0.009 & 0 & 0.003 \\
\hline$W P p$ & 0.000 & 0.005 & 0.070 & 0.957 & 0.546 \\
\hline WP p Šidàk correction & 0.000 & 0.024 & 0.341 & 1.000 & 0.986 \\
\hline Age $<$ NRA $\times$ Low occ. Grade & $-0.180^{\star \star}$ & $0.089+$ & $0.097^{\star \star}$ & -0.006 & 0.003 \\
\hline$W P p$ & 0.001 & 0.025 & 0.004 & 0.152 & 0.524 \\
\hline WP p Šidàk correction & 0.012 & 0.242 & 0.012 & 0.545 & 0.990 \\
\hline Age $<$ NRA $\times$ Mid occ. Grade & -0.108 & 0.008 & $0.085^{\star}$ & 0.001 & 0.006 \\
\hline$W P p$ & 0.011 & 0.827 & 0.007 & 0.629 & 0.115 \\
\hline WP p Šidàk correction & 0.130 & 1.000 & 0.064 & 0.999 & 0.561 \\
\hline Age $<$ NRA $\times$ Low health & $-0.025^{\star}$ & $0.024^{\star \star}$ & -0.011 & $0.020+$ & 0.007 \\
\hline$W P p$ & 0.013 & 0.003 & 0.131 & 0.017 & 0.240 \\
\hline WP p Šidàk correction & 0.081 & 0.036 & 0.615 & 0.256 & 0.824 \\
\hline Age $<$ NRA $\times$ Mid health & 0.005 & 0.008 & -0.014 & 0.005 & -0.004 \\
\hline$W P p$ & 0.645 & 0.359 & 0.120 & 0.056 & 0.564 \\
\hline WP p Šidàk correction & 0.998 & 0.921 & 0.647 & 0.390 & 0.991 \\
\hline \multicolumn{6}{|c|}{ Year-semester of birth dummies (Ref. Category: 1931 - I sem) } \\
\hline 1931 - II sem & $-0.037^{\star \star \star}$ & $0.049^{\star \star \star}$ & $0.033^{\star \star \star}$ & $0.008^{\star \star \star}$ & $0.010^{\star \star \star}$ \\
\hline 1932 - I sem & $-0.075^{\star \star \star}$ & $0.099^{\star \star \star}$ & $0.068^{\star \star \star}$ & $0.011^{\star \star \star}$ & $0.024^{\star \star \star}$ \\
\hline 1932 - II sem & $-0.124^{\star \star \star}$ & $0.141^{\star \star \star}$ & $0.105^{\star \star \star}$ & $0.018^{\star \star \star}$ & $0.033^{\star \star \star}$ \\
\hline 1933 - I sem & $-0.198^{\star \star \star}$ & $0.199^{\star \star \star}$ & $0.141^{\star \star \star}$ & $0.026^{\star \star \star}$ & $0.046^{\star \star \star}$ \\
\hline 1933 - II sem & $-0.200^{\star \star \star}$ & $0.225^{\star \star \star}$ & $0.162^{\star \star \star}$ & $0.029^{\star \star \star}$ & $0.051^{\star \star \star}$ \\
\hline 1934 - I sem & $-0.292^{\star \star \star}$ & $0.324^{\star \star \star}$ & $0.216^{\star \star \star}$ & $0.044^{\star \star \star}$ & $0.075^{\star \star \star}$ \\
\hline 1934 - II sem & $-0.350^{\star \star \star}$ & $0.376^{\star \star \star}$ & $0.263^{\star \star \star}$ & $0.053^{\star \star \star}$ & $0.085^{\star \star \star}$ \\
\hline 1935 - I sem & $-0.421^{\star \star \star}$ & $0.456^{\star \star \star}$ & $0.305^{\star \star \star}$ & $0.065^{\star \star \star}$ & $0.103^{\star \star \star}$ \\
\hline 1935 - II sem & $-0.456^{\star \star \star}$ & $0.500^{\star \star \star}$ & $0.351^{\star \star \star}$ & $0.073^{\star \star \star}$ & $0.111^{\star \star \star}$ \\
\hline 1936 - I sem & $-0.515^{\star \star \star}$ & $0.561^{\star \star \star}$ & $0.389^{\star \star \star}$ & $0.081^{\star \star \star}$ & $0.122^{\star \star \star}$ \\
\hline 1936 - II sem & $-0.534^{\star \star \star}$ & $0.591^{\star \star \star}$ & $0.425^{\star \star \star}$ & $0.076^{\star \star \star}$ & $0.134^{\star \star \star}$ \\
\hline \multicolumn{6}{|c|}{ Year-semester dummies (Ref. Category: 1986 - I sem) } \\
\hline 1986 - II sem & 0.017 & -0.024 & -0.014 & -0.003 & -0.005 \\
\hline 1987 - I sem & $0.069^{\star \star \star}$ & $-0.087^{\star \star \star}$ & $-0.055^{\star \star \star}$ & $-0.012^{\star \star \star}$ & $-0.020^{\star \star \star}$ \\
\hline 1987 - II sem & $0.105^{\star \star \star}$ & $-0.126^{\star \star \star}$ & $-0.083^{\star \star \star}$ & $-0.017^{\star \star \star}$ & $-0.030^{\star \star \star}$ \\
\hline 1988 - I sem & $0.164^{\star \star \star}$ & $-0.186^{\star \star \star}$ & $-0.124^{\star \star \star}$ & $-0.027^{\star \star \star}$ & $-0.044^{\star \star \star}$ \\
\hline 1988 - II sem & $0.200^{\star \star \star}$ & $-0.226^{\star \star \star}$ & $-0.152^{\star \star \star}$ & $-0.033^{\star \star \star}$ & $-0.053^{\star \star \star}$ \\
\hline 1989 - I sem & $0.257^{\star \star \star}$ & $-0.291^{\star \star \star}$ & $-0.194^{\star \star \star}$ & $-0.042^{\star \star \star}$ & $-0.068^{\star \star \star}$ \\
\hline 1989 - II sem & $0.301^{\star \star \star}$ & $-0.339^{\star \star \star}$ & $-0.227^{\star \star \star}$ & $-0.050^{\star \star \star}$ & $-0.079^{\star \star \star}$ \\
\hline 1990 - I sem & $0.359^{\star \star \star}$ & $-0.405^{\star \star \star}$ & $-0.271^{\star \star \star}$ & $-0.059^{\star \star \star}$ & $-0.093^{\star \star \star}$ \\
\hline 1990 - II sem & $0.403^{\star \star \star}$ & $-0.454^{\star \star \star}$ & $-0.306^{\star \star \star}$ & $-0.067^{\star \star \star}$ & $-0.104^{\star \star \star}$ \\
\hline 1991 - I sem & $0.464^{\star \star \star}$ & $-0.491^{\star \star \star}$ & $-0.332^{\star \star \star}$ & $-0.074^{\star \star \star}$ & $-0.118^{\star \star \star}$ \\
\hline
\end{tabular}


Table C3 Continued

\begin{tabular}{|c|c|c|c|c|c|}
\hline & $\begin{array}{l}\text { Pension } \\
\text { benefit }\end{array}$ & Employment & Inactivity & $\begin{array}{c}\text { Disability } \\
\text { benefit }\end{array}$ & $\begin{array}{c}\text { Unemployment } \\
\text { benefit }\end{array}$ \\
\hline 1991 - II sem & $0.521^{\star \star \star}$ & $-0.559^{\star \star \star}$ & $-0.386^{\star \star \star}$ & $-0.082^{\star \star \star}$ & $-0.124^{\star \star \star}$ \\
\hline 1992 - I sem & $0.578^{\star \star \star}$ & $-0.632^{\star \star \star}$ & $-0.427^{\star \star \star}$ & $-0.090^{\star \star \star}$ & $-0.151^{\star \star \star}$ \\
\hline 1992 - II sem & $0.626^{\star \star \star}$ & $-0.680^{\star \star \star}$ & $-0.472^{\star \star \star}$ & $-0.099^{\star \star \star}$ & $-0.148^{\star \star \star}$ \\
\hline 1993 - I sem & $0.660^{\star \star \star}$ & $-0.751^{\star \star \star}$ & $-0.501^{\star \star \star}$ & $-0.108^{\star \star \star}$ & $-0.171^{\star \star \star}$ \\
\hline 1993 - II sem & $0.689^{\star \star \star}$ & $-0.802^{\star \star \star}$ & $-0.541^{\star \star \star}$ & $-0.116^{\star \star \star}$ & $-0.167^{\star \star \star}$ \\
\hline 1994 - I sem & $0.757^{\star \star \star}$ & $-0.887^{\star \star \star}$ & $-0.597^{\star \star \star}$ & $-0.128^{\star \star \star}$ & $-0.199^{\star \star \star}$ \\
\hline 1994 - II sem & $0.737^{\star \star \star}$ & $-0.904^{\star \star \star}$ & $-0.611^{\star \star \star}$ & $-0.131^{\star \star \star}$ & $-0.195^{\star \star \star}$ \\
\hline 1995 - I sem & $0.772^{\star \star \star}$ & $-0.938^{\star \star \star}$ & $-0.622^{\star \star \star}$ & $-0.133^{\star \star \star}$ & $-0.208^{\star \star \star}$ \\
\hline 1995 - II sem & $0.835^{\star \star \star}$ & $-0.993^{\star \star \star}$ & $-0.676^{\star \star \star}$ & $-0.143^{\star \star \star}$ & $-0.221^{\star \star \star}$ \\
\hline 1996 - I sem & $0.825^{\star \star \star}$ & $-1.025^{\star \star \star}$ & $-0.685^{\star \star \star}$ & $-0.146^{\star \star \star}$ & $-0.228^{\star \star \star}$ \\
\hline 1996 - II sem & $0.866^{\star \star \star}$ & $-1.053^{\star \star \star}$ & $-0.698^{\star \star \star}$ & $-0.146^{\star \star \star}$ & $-0.231^{\star \star \star}$ \\
\hline 1997 - I sem & $0.947^{\star \star \star}$ & $-1.129^{\star \star \star}$ & $-0.749^{\star \star \star}$ & $-0.154^{\star \star \star}$ & $-0.259^{\star \star \star}$ \\
\hline 1997 - II sem & $0.948^{\star \star \star}$ & $-1.153^{\star \star \star}$ & $-0.765^{\star \star \star}$ & $-0.155^{\star \star \star}$ & $-0.261^{\star \star \star}$ \\
\hline 1998 - I sem & $0.993^{\star \star \star}$ & $-1.201^{\star \star \star}$ & $-0.770^{\star \star \star}$ & $-0.152^{\star \star \star}$ & $-0.275^{\star \star \star}$ \\
\hline 1998 - II sem & $1.092^{\star \star \star}$ & $-1.274^{\star \star \star}$ & $-0.838^{\star \star \star}$ & $-0.163^{\star \star \star}$ & $-0.288^{\star \star \star}$ \\
\hline 1999 - I sem & $1.089^{\star \star \star}$ & $-1.319^{\star \star \star}$ & $-0.846^{\star \star *}$ & $-0.162^{\star \star \star}$ & $-0.303^{\star \star \star}$ \\
\hline 1999 - II sem & $1.129^{\star \star \star}$ & $-1.357^{\star \star \star}$ & $-0.865^{\star \star \star}$ & $-0.155^{\star \star \star}$ & $-0.310^{\star \star \star}$ \\
\hline 2000 - I sem & $1.268^{\star \star \star}$ & $-1.439^{\star \star \star}$ & $-0.941^{\star \star \star}$ & $-0.169^{\star \star \star}$ & $-0.336^{\star \star \star}$ \\
\hline 2000 - II sem & $1.246^{\star \star \star}$ & $-1.470^{\star \star \star}$ & $-0.949^{\star \star \star}$ & $-0.161^{\star \star \star}$ & $-0.341^{\star \star \star}$ \\
\hline 2001 - I sem & $1.285^{\star \star \star}$ & $-1.498^{\star \star \star}$ & $-0.921^{\star \star \star}$ & $-0.136^{\star \star \star}$ & $-0.344^{\star \star \star}$ \\
\hline 2001 - II sem & $1.326^{\star \star \star}$ & $-1.545^{\star \star \star}$ & $-0.969^{\star \star \star}$ & $-0.136^{\star \star \star}$ & $-0.344^{\star \star \star}$ \\
\hline 2002 - I sem & $1.386^{\star \star \star}$ & $-1.627^{\star \star \star}$ & $-1.099^{\star \star \star}$ & $-0.149^{\star * \star}$ & $-0.369^{\star \star \star}$ \\
\hline \multicolumn{6}{|c|}{ Age dummies (Reference Category: 55 years old) } \\
\hline 56 & $-0.099^{\star \star \star}$ & $0.106^{\star \star \star}$ & $0.074^{\star \star \star}$ & $0.016^{\star \star \star}$ & $0.024^{\star \star \star}$ \\
\hline 57 & $-0.198^{\star \star \star}$ & $0.216^{\star \star \star}$ & $0.151^{\star \star \star}$ & $0.033^{\star \star \star}$ & $0.049^{\star \star \star}$ \\
\hline 58 & $-0.293^{\star \star \star}$ & $0.329^{\star \star \star}$ & $0.228^{\star \star \star}$ & $0.050^{\star \star \star}$ & $0.074^{\star \star \star}$ \\
\hline 59 & $-0.381^{\star \star \star}$ & $0.437^{\star \star \star}$ & $0.303^{\star \star \star}$ & $0.066^{\star \star \star}$ & $0.097^{\star \star \star}$ \\
\hline 60 & -0.152 & $0.123^{\star \star \star}$ & $0.595^{\star \star \star}$ & $0.160^{\star \star \star}$ & $0.250^{\star \star \star}$ \\
\hline 61 & -0.111 & 0.021 & $0.595^{\star \star \star}$ & $0.163^{\star \star \star}$ & $0.212^{\star \star \star}$ \\
\hline 62 & -0.125 & 0.035 & $0.641^{\star \star \star}$ & $0.170^{\star \star \star}$ & $0.216^{\star \star \star}$ \\
\hline 63 & -0.158 & $0.074^{\star \star}$ & $0.684^{\star \star \star}$ & $0.175^{\star \star \star}$ & $0.229^{\star \star \star}$ \\
\hline 64 & -0.219 & $0.131^{\star \star \star}$ & $0.725^{\star \star \star}$ & $0.176^{\star \star \star}$ & $0.247^{\star \star \star}$ \\
\hline 65 & -0.255 & $0.192^{\star \star \star}$ & $0.764^{\star \star \star}$ & $0.185^{\star \star \star}$ & $0.268^{\star \star \star}$ \\
\hline _cons & $0.126^{\star \star}$ & $1.033^{\star \star \star}$ & 0.04 & $-0.068^{\star \star \star}$ & $-0.051^{\star \star \star}$ \\
\hline Adj. $R^{2}$ & 0.69 & 0.62 & 0.15 & 0.05 & 0.07 \\
\hline Observations & 371,622 & 371,622 & 371,622 & 371,622 & 371,622 \\
\hline
\end{tabular}

Notes: The table displays the estimated DD coefficient $\beta$ of Eq. (2) interacted simultaneously with different socio-economic group indicators separately for each of the outcomes (columns). ${ }^{\text {a }}$ ef. category composed of the three excluded categories: workers with high wage, high occupational grade (executives), and good health. SE clustered at period level with WB procedure with 999 repetitions. Šidàk correction for six multiple hypotheses. Significance levels: ${ }^{\star \star \star} 1 \%,{ }^{\star \star} 5 \%,{ }^{\star} 10 \%$, based on: (a) WB procedure with 999 repetitions and Šidàk correction for six multiple hypotheses for the term Age $<$ NRA interacted with socio-economic group indicators, and (b) SE clustered for the remaining coefficients.

DD, difference-in-differences; NRA, normal retirement age; WB, wild-cluster bootstrap. 


\section{Appendix D}

Table D1 Effect of raising the NRA: Eq. 2 controlling also for Individual Fixed Effects

\begin{tabular}{llllll}
\hline & $\begin{array}{c}\text { Pension } \\
\text { benefit }\end{array}$ & Employment & Inactivity & $\begin{array}{c}\text { Disability } \\
\text { benefit }\end{array}$ & $\begin{array}{c}\text { Unemployment } \\
\text { benefit }\end{array}$ \\
\hline Age $<$ NRA & $-\mathbf{0 . 4 4 0 \star \star \star}$ & $\mathbf{0 . 0 8 7 ^ { \star \star \star }}$ & $\mathbf{0 . 1 3 4} 4^{\star \star \star}$ & $\mathbf{0 . 0 4 2 * \star \star}$ & $\mathbf{0 . 0 1 6}$ \\
WB $p$ & 0.000 & 0.000 & 0.000 & 0.000 & 0.045 \\
WB Šidàk $p$ & 0.000 & 0.000 & 0.000 & 0.000 & 0.206 \\
\hline Adj. $R^{2}$ & 0.77 & 0.61 & 0.54 & 0.63 & 0.35 \\
Observations & 659,428 & 659,428 & 659,428 & 659,428 & 659,428 \\
\hline
\end{tabular}

Notes: The table displays the estimated DD coefficient $\beta$ of Eq. (2) separately for each of the outcomes (columns). Controls include all those specified in Eq. (2) plus individuals fixed effects. SE clustered at period level. WB procedure with 999 repetitions. Significance legend based on WB $p$-value corrected for five multiple hypotheses: ${ }^{\star \star \star} 1 \%$, ${ }^{\star \star} 5 \%,{ }^{\star} 10 \%$.

DD, difference-in-differences; NRA, normal retirement age; WB, wild-cluster bootstrap.

Table D2 Effect of raising the NRA: Eq. 2 excluding from controls time fixed effects

\begin{tabular}{lclllc}
\hline & $\begin{array}{c}\text { Pension } \\
\text { benefit }\end{array}$ & Employment & Inactivity & $\begin{array}{c}\text { Disability } \\
\text { benefit }\end{array}$ & $\begin{array}{c}\text { Unemployment } \\
\text { benefit }\end{array}$ \\
\hline Age $<$ NRA & $\mathbf{- 0 . 4 5 4 ^ { \star \star \star }}$ & $\mathbf{0 . 0 9 0 ^ { \star \star }}$ & $\mathbf{0 . 1 6 1 ^ { \star \star }}$ & $\mathbf{0 . 0 4 3 ^ { \star \star \star }}$ & $-\mathbf{0 . 0 1 9}^{\star}$ \\
WB $p$ & 0.000 & 0.007 & 0.002 & 0.000 & 0.016 \\
WB Šidàk $p$ & 0.000 & 0.035 & 0.010 & 0.000 & 0.070 \\
\hline Adj. $R^{2}$ & 0.77 & 0.61 & 0.54 & 0.63 & 0.35 \\
Observations & 659,428 & 659,428 & 659,428 & 659,428 & 659,428 \\
\hline
\end{tabular}

Notes: The table displays the estimated DD coefficient $\beta$ of Eq. (2) separately for each of the outcomes (columns). Controls include all those specified in Eq. (2) except for time-fixed effects. SE clustered at period level. WB procedure with 999 repetitions. Significance legend based on WB $p$-value corrected for five multiple hypotheses: ${ }^{* \star *} 1 \%$, ${ }^{*} 5 \%$, ${ }^{\star} 10 \%$.

DD, difference-in-differences; NRA, normal retirement age; WB, wild-cluster bootstrap.

Table D3 Effect of raising the NRA: Eq. 2 excluding years 1992-1993

\begin{tabular}{|c|c|c|c|c|c|}
\hline & $\begin{array}{l}\text { Pension } \\
\text { benefit }\end{array}$ & Employment & Inactivity & $\begin{array}{c}\text { Disability } \\
\text { benefit }\end{array}$ & $\begin{array}{c}\text { Unemployment } \\
\text { benefit }\end{array}$ \\
\hline$\overline{\text { Age }}<$ NRA & $-0.417^{\star \star \star}$ & $0.078^{\star \star \star}$ & $0.127^{\star \star \star}$ & $0.043^{\star \star \star}$ & 0.015 \\
\hline WB $p$ & 0.000 & 0.004 & 0.004 & 0.000 & 0.047 \\
\hline WB Šidàk $p$ & 0.000 & 0.020 & 0.020 & 0.000 & 0.214 \\
\hline$\overline{\operatorname{Adj} .} R^{2}$ & 0.64 & 0.24 & 0.1 & 0.02 & 0.05 \\
\hline Observations & 539,532 & 539,532 & 539,532 & 539,532 & 539,532 \\
\hline
\end{tabular}

Notes: The table displays the estimated DD coefficient $\beta$ of Eq. (2) separately for each of the outcomes (columns). Controls include all those specified in Eq. (2). Years 1992-1993 excluded from the analysis. SE clustered at period level. WB procedure with 999 repetitions. Significance legend based on WB $p$-value corrected for five multiple hypotheses: ${ }^{\star \star \star} 1 \%$, ${ }^{\star}{ }^{\star} 5 \%,{ }^{\star} 10 \%$.

DD, difference-in-differences; NRA, normal retirement age; WB, wild-cluster bootstrap. 
Table D4 Effect of raising the NRA: Eq. 2 excluding individuals with $<15$ years of contributions in 1992

\begin{tabular}{llllll}
\hline & $\begin{array}{c}\text { Pension } \\
\text { benefit }\end{array}$ & Employment & Inactivity & $\begin{array}{c}\text { Disability } \\
\text { benefit }\end{array}$ & $\begin{array}{c}\text { Unemployment } \\
\text { benefit }\end{array}$ \\
\hline Age<NRA & $-\mathbf{0 . 4 4 0 * \star \star}$ & $\mathbf{0 . 0 8 7 ^ { \star \star \star }}$ & $\mathbf{0 . 1 3 3 ^ { \star \star \star }}$ & $\mathbf{0 . 0 4 2}{ }^{\star \star \star}$ & $\mathbf{0 . 0 1 6 ^ { \star \star }}$ \\
WB $p$ & 0.000 & 0.000 & 0.000 & 0.000 & 0.001 \\
WB Šidàk $p$ & 0.000 & 0.000 & 0.000 & 0.000 & 0.005 \\
\hline Adj. $R^{2}$ & 0.64 & 0.22 & 0.1 & 0.02 & 0.05 \\
Observations & 657,756 & 657,756 & 657,756 & 657,756 & 657,756 \\
\hline
\end{tabular}

Notes: The table displays the estimated DD coefficient $\beta$ of Eq. (2) separately for each of the outcomes (columns). SE clustered at period level. WB procedure with 999 repetitions. Significance based on WB $p$-value corrected for five multiple hypotheses: ${ }^{\star \star \star} 1 \%,{ }^{\star \star} 5 \%,{ }^{\star} 10 \%$.

DD, difference-in-differences; NRA, normal retirement age; WB, wild-cluster bootstrap.

Table D5 Change in the pension base (average of last $N$ years of wages before pension claiming)

\begin{tabular}{lcc}
\hline $\mathbf{N}$ Years & Avg. Annual Wage over $\mathbf{N}$ years & \% change from $\mathbf{N}$ to $\mathbf{N}+\mathbf{1}$ \\
\hline 5 & $24,905.47$ & \\
6 & $24,832.08$ & $-0.3 \%$ \\
7 & $24,752.02$ & $-0.3 \%$ \\
8 & $24,696.57$ & $-0.2 \%$ \\
9 & $24,663.13$ & $-0.1 \%$ \\
10 & $24,631.77$ & $-0.1 \%$ \\
\hline
\end{tabular}

Note: Author's calculation on the final sample of analysis using WHIP data.

WHIP, Working Histories Italian Panel.

Table D6 Effect of raising the NRA on Old-age pension and Early pension types (Eq. 2)

\begin{tabular}{lcc}
\hline & Old age pension benefits & Early pension benefits \\
\hline \hline Age $<$ NRA & $\mathbf{- 0 . 5 4 9 \star \star \star}$ & $\mathbf{- 0 . 0 2 5}$ \\
WB $p$ & 0.000 & 0.379 \\
WB Šidàk $p$ & 0.000 & 0.907 \\
\hline Adj. $R^{2}$ & 0.75 & 0.51 \\
Observations & 551,034 & 108,394 \\
\hline
\end{tabular}

Notes: The table displays the estimated DD coefficient $\beta$ of Eq. (2) separately for the outcomes "Old-age Pension" and "Early Pension" which includes both seniority pension and other early pension options. Controls include all those specified in Eq. (2). SE clustered at period level. WB procedure with 999 repetitions. Significance legend based on WB $p$-value corrected for two multiple hypotheses: ${ }^{\star \star \star} 1 \%$, ${ }^{\star \star} 5 \%,{ }^{\star} 10 \%$.

DD, difference-in-differences; NRA, normal retirement age; WB, wild-cluster bootstrap. 


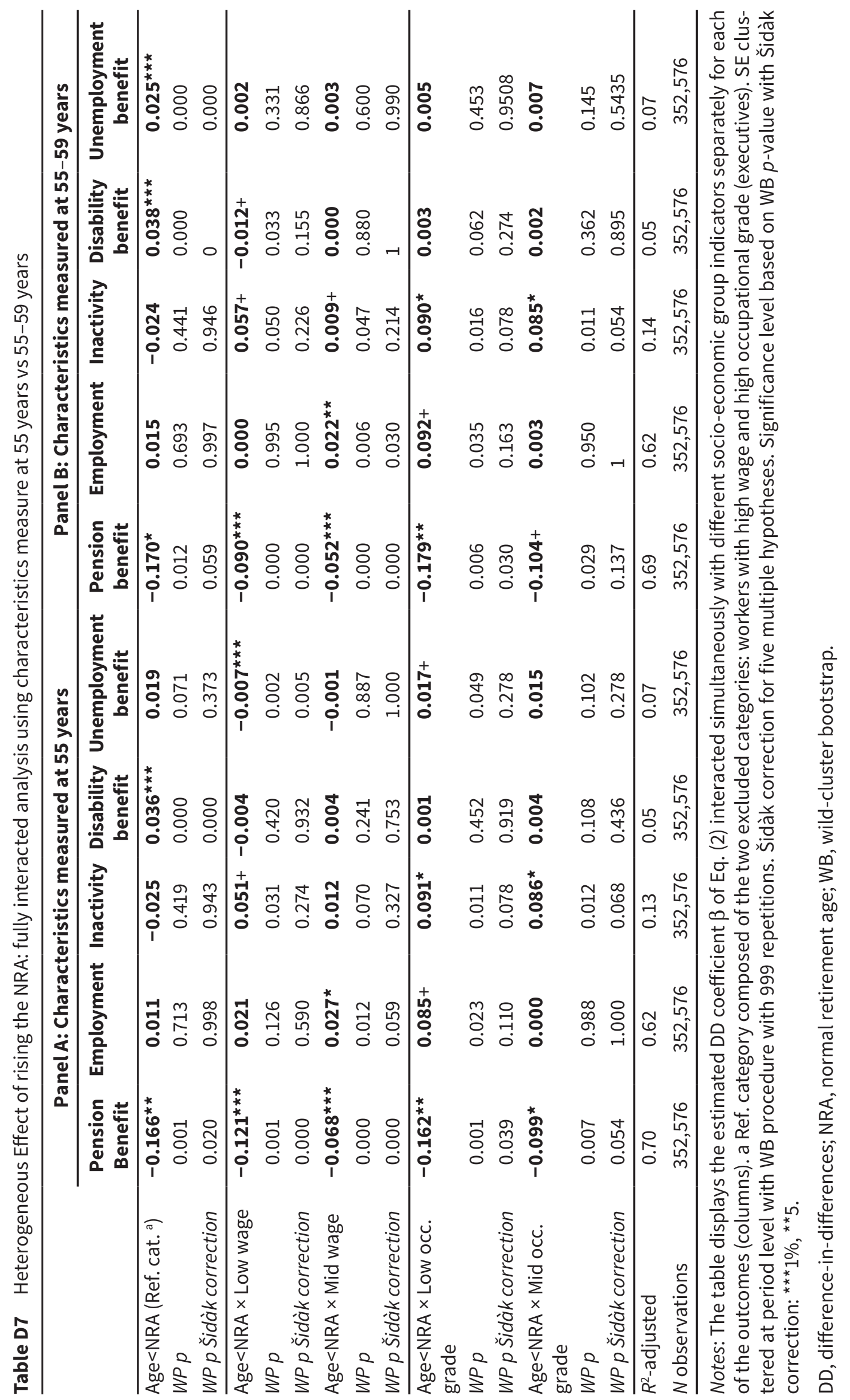

